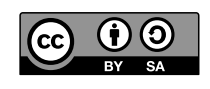

DOI: $10.4312 / \mathrm{mz} \cdot 57.2 .5-64$

UDK 78.085(497.4Ljubljana)"18":94(497.4 Ljubljana)"1821"

\title{
Laibacher Deutscher after the Congress of Laibach
}

\author{
Lidija Podlesnik Tomášiková, ${ }^{a}$ Marko Motnik ${ }^{\mathrm{b}}$ \\ ${ }^{a}$ National and University Library of Slovenia, Ljubljana \\ ${ }^{b}$ Research Centre of the Slovenian Academy of Sciences and Arts, Ljubljana
}

\begin{abstract}
Behind the scenes of the Congress of Laibach (modern day Ljubljana), a dance form called Deutscher came into existence and for a decade remained, in a specific local version, the most popular dance of bourgeois circles. This paper sheds light on the phenomenon of the Laibacher Deutscher within a broad social and cultural context and political background.
\end{abstract}

Keywords: Ljubljana, Congress of Laibach, dance music, social dances, Deutscher, waltz

\section{IZVLEČEK}

V senci dogajanja na ljubljanskem kongresu je v Ljubljani zaživela plesna oblika $\mathrm{z}$ imenom Deutscher in se eno desetletje obdržala v specifično lokalni obliki kot najbolj priljubljen ples meščanskih krogov. V prispevku je osvetljen fenomen ljubljanskega Deutscherja v širšem družbeno-kulturnem kontekstu in s širšim političnim ozadjem.

Ključne besede: Ljubljana, ljubljanski kongres, plesna glasba, družabni plesi, Deutscher, valček

* The article was written within the research programme Researches in the History of Music in Slovenia (P6-0004), funded by the Slovenian Research Agency (ARRS), and in cooperation with the National and University Library of Slovenia, Ljubljana (NUK). 


\section{Introduction}

Some European social dance forms, such as the Allemande, the Anglaise, the Ecossaise, or the Polonaise, indicate in their naming both their geographical origins as well as their interwovenness with the character of the local population of a given land. ${ }^{1}$ Geographical classification has been maintained over the centuries in written sources as an important attribute of social dances, and the association of some dances with towns has also been noteworthy. In this respect, the Viennese Waltz, which began its triumphal march more than two hundred years ago, is certainly the most significant. Coinciding with the waltz is the emergence of the hitherto largely overlooked Laibacher Deutscher, which, unlike its giddy and at that time still young competitor, can be described as both an attempt at restoration and an epilogue to one of Europe's oldest social dances, the German Dance. Its two representative forms, the Laibacher Redout-Deutscher and the Laibacher Schießstatt-Deutscher, performed in Ljubljana's dance halls in the decade after the Congress of Laibach, provided the educated classes with a useful opportunity to consolidate their affiliation to German bourgeois culture.

\section{The German Dance: an Enigma in Dance History}

Despite the fact that for centuries the German Dance has appeared in the sources under various names, to this day, this chapter of European dance history remains poorly researched and undefined. The term Deutscher (a freestanding adjective of Deutscher Tanz) is used to refer to a social dance in triple time, often found in the towns of southern Germany and the Habsburg domains in the second half of the eighteenth century and the first decades of the nineteenth century. ${ }^{2}$ The expression can therefore also be applied to the Laibacher Deutscher.

Neither the primary sources nor the scholarly literature provide a unified conception of the phenomenon of the German Dance, giving the impression of a historical disconnection between this dance form and the earlier sixteenthcentury Allemande. Of course, the German Dance has evolved significantly over the centuries, but the roots of the Deutscher appear to be traceable to the sixteenth century, or perhaps to an even earlier period. The fact that the term Deutscher Tanz has often been used generically also causes confusion and misunderstanding: it was used as a superordinate term for a range of dances from the German-speaking

1 Joan Rimmer, "Allemande, Balletto and Tanz," Music \& Letters 70, no. 2 (1989): 226, https://doi. org $/ 10.1093 / \mathrm{ml} / 70.2 .226$.

2 "Als Deutscher Tanz wird heute im allgemeinen ein dreischlägiger Gesellschaftstanz bezeichnet, der von der zweiten Hälfte des 18. bis zu Beginn des 19. Jh. vorwiegend in der städtischen Gesellschaft des süddeutschen Raumes und in Österreich gebräuchlich war." Walburga Litschauer and Walter Deutsch, "Deutscher Tanz," in MGG Online, accessed June 30, 2021, https://www. $\mathrm{mgg}$-online.com/mgg/stable/12484. 
area, whether Deutscher, Dreier (Drehtanz), Ländler, Schleifer, Steirisch (Steirer), Straßburger, Schwäbischer Tanz and, just as importantly, the waltz.

The term Allemande also appears in this context, but this is not meant to refer to the instrumental musical form of the eighteenth century, nor to the Allemande, a French dance of the eighteenth century. On the contrary, the Allemande is merely a more genteel name which also found favour on the broad European music market. ${ }^{3}$ This extreme flexibility and openness in titling of dance compositions is a common cause for incertitude and misapprehension. ${ }^{4}$

\section{Choreographic Elements of the German Dance}

Dancers previously trained in the steps of the minuet and the complex sequence of figures of the contredanse apparently mastered the Deutscher swiftly and effortlessly, requiring no special instruction. The Deutscher is thus not explained in dance manuals. Brief references to choreographic structures are occasionally found in dance treatises, but these seldom originate from the geographical environment or time period in question and thus rarely prove useful.

Some brief pointers are given, for example, in the Erweiterung der Kunst nach der Chorographie zu tanzen [...], published in 1772 by Carl Joseph von Feldtenstein, a dancing master in Braunschweig. It is clear from the description that, contrary to a minuet or contredanse, the Deutscher did not need dance instruction, a "supple and loose knee" being sufficient for the execution of its basic step "in three parts." The Deutscher's double step was easy to capture with three-part music, which Feldtenstein likened to the three blows of a blacksmith's hammer. The performance in the space was to be unrestricted and at the discretion of the dancing couple, meaning that it was not guided or otherwise regulated by the dancing master: "Each male dancer can steer his female partner according to his own liking, with circular turns and rounds." For the

3 E.g. Joseph Haydn, Six Allemandes à plusieurs Instrumens: Composées par Joseph Haydn à Vienne chez Artaria Comp. No. 76 [1787], Hob. IX:9. The same dances are even referred to as Menuettini Tedeschi in the transcription by the copyist Johann Nepomuk Rainprecht (Salzburg, Erzabtei St. Peter, Musikalienarchiv). See RISM ID no. 600501145.

4 Here are just three examples of ambiguous titles on the covers of music prints by the Viennese publisher Artaria \& Comp.: the 1811 print by Ignaz Moscheles is labelled 10 Deutsche or Walzer, the 1812 edition by Mauro Giuliani is entitled 16 Ländler or Valses autrichiennes, and the 1814 edition by the same composer is labelled 12 Ländler or Walzer. Wolfgang Amadeus Mozart's German Dances KV 536 and KV 567 were also published as XII Walzer pour le Piano-Forte avec Flute ou Violon by Nikolaus Simrock in Bonn around 1802. Under a similar title (Douze walzes) Mozart's Deutsche were issued by the London publisher G. Walker around 1817. The first edition of these dances by the publisher Artaria in Vienna (1789) is entitled 12 Deutsche-Taenze.

5 "Jeder Tänzer kann seine Tänzerin nach eigenen Gefallen, durch Cirkelwendungen und Touren in Bewegung setzen." C. J. von Feldtenstein, Erweiterung der Kunst nach der Chorographie zu tanzen, Tänze zu erfinden, und aufzusetzen; wie auch Anweisung zu verschiedenen National-Tänzen; Als zu Englischen, Deutschen, Schwäbischen, Pohlnischen, Hannak-Masur-Kosak- und Hungarischen; mit Kupfern; nebst einer Anzabl Englischer Tänze (Braunschweig: [s. n.], 1772), 100. 
sake of safety on the dance floor, the couples were merely required to maintain order, i.e. to move without jostling or overtaking other couples: "Also, each couple, especially in the German Dances, must remain in the order in which they begin. Dancing outside the initial circle is not allowed [...]."

An example of a similar performance of the Deutscher was described by Johann Wolfgang von Goethe in his 1774 novel Die Leiden des jungen Werthers (The Sorrows of Young Werther). Goethe describes a sequence of dances at the dance party attended by young bourgeois society at a country estate (Lusthaus) on 16 June $1771 .^{7}$ Dances began with a group minuet followed by contredances and ended with a Deutscher, the latter holding special significance for couples in love, as it provided them with an opportunity for closeness while dancing. ${ }^{8}$ Goethe described Werther and Lotte's dance as a German Dance consisting of a figure where the arms are interlocked in various ways (Straßburger), followed by the spinning of the couples (Walzen) and concluding with a few turns through the hall at a walking pace in order to rest. ${ }^{9}$

Slightly closer in time and place to the Laibacher Deutscher is Georg Link's dance booklet printed in 1796 by the printer Franz Joseph Jenko in Celje, then at the southern border of Styria. The work is entitled Vollkommene Tanzschule aller Kompagnien und Bällen vorkommenden Tänzen ${ }^{10}$ and contains twelve new English contredances (Contre-Tänze) with notations of pathways and figures, which are also graphically depicted on the accompanying copperplates. The Deutscher is not described by Link, but in his English contredances he mingled the figures of

6 "Auch hat jedes Paar, besonders bei denen Deutsch-Tänzen in dieser Ordnung, in welcher angefangen wird, zu verbleiben, und wird insbesondere verbothen, ausser seinem angefangenen Kreise hinaus zu tanzen [...]." Ball-Ordnung für die Faschingszeit 1793, Wien. Quoted in Verena Brunner, Contredanses: Tanzvergnügen der Mozart-Zeit; Kontratänze, Tanzbeschreibungen, Historisches (Boppart am Rhein: Fidula-Verlag, 2014), 74. A similar statement can be found in Christian Länger, Terpsichore: Ein Taschenbuch der neuesten gesellschaftlichen Tänze, worin zugleich Anweisung gegeben wird, wie man 40 Touren und 76 Tänze ohne orchesigraphische Zeichnungen und ohne Lehrer erlernen kann: Zum Nutzen und Vergnügen für Freunde der Tanzkunst (Würzburg: Etlinger, 1824), 179: "When spinning, no dancing couple may cross the lines; also, the dancing line, especially if there are many, may not move all at once, but 2,3, at most 4 couples separate from the stationary row to rejoin on the other side, and wait until the row rejoins them." ("Beim Walzen darf kein tanzendes Paar die Reihen überschreiten; auch darf die tanzende Colonne, besonders bei großer Anzahl, sich nicht auf einmal fortbewegen, sondern 2, 3, höchstens 4 Paare trennen sich von der stillstehenden Reihe, um sich auf der andern Seite wieder anzuschließen, und abzuwarten, bis die Reihe wieder an sie gelangt.")

7 Johann Wolfgang von Goethe, Die Leiden des jungen Werthers (Leipzig: Weygandsche Buchhandlung, 1774), 26-44.

8 Reingard Witzmann, "Magie der Drehung - Zum Phänomen des Wiener Walzers von der Aufklärung zum Biedermeier," in Zur Frübgeschichte des Walzers, eds. Thomas Nußbaumer and Franz Gratl, Schriften zur musikalischen Ethnologie 3 (Innsbruck: Universitätsverlag Wagner, 2014), 18.

9 Reingard Witzmann, Der Ländler in Wien (Wien: Arbeitsstelle für den Volkskundeatlas in Österreich, 1976), 37.

10 Georg Link moved to Prague from Denmark with his brother Johann Peter. They worked as dancers in ballet companies in Vienna, Graz, Bratislava, Salzburg and finally Innsbruck. Pia Brocza and Marko Motnik, “Georg Link und seine Tanzschule von 1796,” De musica disserenda 10, no. 2 (2014): 33-39. 
the contredances with those of other dances. In contredanse no. 10, for instance, he added two distinctive figures of the Deutscher, namely the Strasbourg figure of the interlacing arms above the head and the promenade in a circle.

Even more instructive is the English contredanse no. 11, where Link combined the minuet step and the two aforementioned Deutscher figures with those of the contredance, but with the difference that instead of the usual promenade he prescribed a German turn (deutsche Tour) in a circle with spinning of the couples (Walzen). There is no music included in Link's manual, but the example of contredanse no. 11 shows that at the turn of the eighteenth to the nineteenth century the minuet step was easily replaced by the waltz step during the dance. It is also clear from Link's description that he understood "Deutsch" in two different contexts: the Strasbourg figures with the promenade (couples walking in a circle) and the Strasbourg figures with the German turn, which is performed by spinning in a circle. ${ }^{11}$ Link's choreography strongly resembles Goethe's description, although his choreographic elements are described in brief and condensed form, whereas Goethe's text undoubtedly contains longer, free-standing dance passages.

Although no precise choreographic descriptions are available, a variety of sources permit us to identify some characteristic features of early Deutscher, before 1800. It is a social dance, in pairs, and possesses at least three characteristic elements: a promenade or circling of the couple, interlacing of arms (Straßburger), and spinning (Walzen). The relative openness of the form is characteristic, as the choreographic structure of the dance was not standardised. More numerous and eloquent than the choreographic descriptions are the critiques and moral concerns regarding German Dances. ${ }^{12}$ The sources are full of warnings, prohibitions, and expressions of distaste. Critics were disturbed by the morally questionable close physical proximity of the dancing couple and what they considered to be wild dancing, especially spinning, deemed unhealthy. Although many of these concerns seem trivial and excessive today, the fact remains that the Deutscher's character differed significantly from the graceful, refined and elegant salon dances of the time, and was even further removed from the restrained and rigid minuet, whose every aspect was strictly regulated. ${ }^{13}$

\section{The Deutscher in Vienna}

Research surrounding the dynamic evolutionary processes of German Dances shows that the evaluation of a single source does not lead to clear results.

11 By the term Deutsch, Link describes the combination of a Strasbourg figure with a promenade or waltz, performed in a dance circle. The four-part English contredanse consists of a sequence of two minuet figures, two consecutive Deutscher figures and four contredanse figures. Witzmann, Der Ländler in Wien, 34.

12 See e.g. Neuestes Sittengemählde von Wien (Wien: Anton Pichler, 1801), 109.

13 See e.g. Bernard Specht, Ueber Anstand, Schönheit und Grazie im Tanz: Nebst einem Vorschlage zur allgemeinen Balltracht (Prag: [s. n.], 1789), 32-33. 
Clearer lines of development only emerge through the synthesis of a wide variety of documents, as, for example, the studies of the researcher Reingard Witzmann. Witzmann was able to establish that references to the Deutscher as a specific dance form began to appear more frequently in Vienna shortly after 1760, whereas in other parts of the Habsburg Empire, mentions of the Deutscher increased in number only after 1800 . Both in Vienna and beyond, the sources clearly associate Deutscher with the bourgeois milieu. ${ }^{14}$ From the end of the eighteenth century onwards, the characteristic image of the Deutscher took shape in the cities, where numerous composers, some still known to us today and others fallen into oblivion, catered to the needs of a dance-hungry society with fresh, new compositions.

In his notes dating around 1760, the Viennese linguist Valentin Popowitsch (Popovič), a native of the Celje area, distinguished between two forms of German Dances: the Deutscher, which he equates with the Steirisch, and a group of dances he calls the Ländlerische Tänze. Despite the misleading name, the latter are in fact the so-called Walzen ("danser à la Allemande"). They are characterised by jumping and spinning ("Hüpfen und Drehen"), which was also popular among the nobility in Popowitsch's time. However, the term "Steyrisch tanzen" was avoided by the upper classes as it did not sound sufficiently genteel. Couples did not circle in the Steyrisch in question, but rather, the female dancer moved in front of her male partner, who followed her, jumping and stamping his feet. ${ }^{15}$ By Steyrisch, Popowitsch probably meant a more "folk" version of German Dances, whereas his Ländlerische Tänze were bourgeois dances. ${ }^{16}$ These same dances were called Deutscher by sources a few years later.

In the last decades of the eighteenth century, and especially after the reforms of Joseph II, dance events were opened up to the wider society and enthusiasm for dancing consequently increased among the general population. The Deutscher then became one of the most fashionable and, in fact, one of the few dances at dance events, alongside the minuet and the contredanse. In line with the ideas of the Enlightenment, the strict regulations in dance halls were relaxed and every individual felt called upon to dance. ${ }^{17}$

14 Reingard Witzmann, "Der sogenannte 'Deutsche Tanz': Ein Beitrag zur Erforschung der Choreographie des Ländlers," Jahrbuch des Österreichischen Volksliedwerkes 25 (1976): 100-108; Witzmann, Der Ländler in Wien, 46-81.

15 Johann Siegmund Valentin Popowitsch, Vocabula Austriaca et Stiriaca: Nach der Abschrift von Anton Wasserthal herausgegeben, ed. Richard Reutner, Schriften zur deutschen Sprache in Österreich 23, (Frankfurt am Main: Peter Lang, 2004), 1: 670 and 1: 724.

16 In 1767, the ballet master Noverre also described the rural form of the German Dance as a lovely and natural folk dance, danced in the open air around a tree or a pillar in a common circle, with the coordination and skill of the dancing couples. He emphasised the characteristic spatial figure of the couples dancing in a common circle. Jean Georges Noverre, Lettres sur la Danse, et sur les Ballets, par M. Noverre, Maître des Ballets de Son Altesse Sérénissime Monseigneur le Duc de Wurtemberg, E ci-devant des Théatres de Paris, Lyon, Marseille, Londres, E̋c. (Lyon: Aimé Delaroche, 1760), 357-358.

Witzmann, "Magie der Drehung," 13. 
The speed of the Deutscher, especially while spinning, increased: from a leisurely pace soon after 1780, it gradually developed into the so-called Langaus in the years between about $1790-1810^{18}$ and later into a waltz. These dances, which were also called Deutsche by the literati at the time of the Congress of Vienna (1814), are therefore nothing more than an independent element of the couples' spinning at an extremely fast tempo. Already in the Langaus, the dancing couple separated themselves from the precisely defined and regulated order of the group's choreography. The dance thus lost its representational character and became a source of entertainment. While the older form of the Deutscher around 1760 still shows the initial position of the couple side by side, in the Langaus and later in the waltz, the position of the couple is closed, the female dancer and her partner standing facing each other.

In Vienna, the Deutscher seems first to have lost the figure of interlocking arms (Straßburger) soon after 1770, and subsequently the previously characteristic promenade of couples in a circle. The spinning became the only choreographic element of this dance. ${ }^{19}$ The expression Deutscher was dropped once the circular path of the spinning couples also lost its significance, giving way to the practice of rotating around freely on the dance floor; the name Wiener Walzer thus appeared and replaced the Deutscher. However, the Deutscher did not completely vanish once the waltz flourished: it remained in the shadow of the waltz at least until the early 1830 s, and the two dances continued to coexist for a considerable period. ${ }^{20}$

From today's perspective, it is clear that it was the figure of spinning that had the greatest dance potential and therefore became independent and thrived on its own as the waltz. Rotation, which has been mentioned in connection with German Dances for centuries, ${ }^{21}$ is an integral element of the Deutscher, but unlike the waltz, it is not its only figure. The transition between the two dances is smooth and subtle, which may explain why the dance compositions often appear

18 Erich Schenk, "Der Langaus," Studia Musicologica Academiae Scientiarum Hungaricae 3, no. 1 (1962): 301-316.

19 Johann Friedel wrote as early as 1784 that German dancing (Deutschtanzen) is nothing but continuous spinning. Johann Friedel, Galanterien Wiens, auf einer Reise gesammelt, und in Briefen geschildert von einem Berliner ([Wien]: [s. n.], 1784), 1: 144. Friedrich Nicolai, a visitor to Vienna, expressed himself in a similar vein, saying that Austrian dancing is far calmer than is usually imagined in the North and consists only of spinning: "Er besteht bloß aus fortgehendem Walzen von einer Anzahl tanzender Paare." Friedrich Nicolai, Bescbreibung einer Reise durch Deutschland und die Schweiz, im Jahre 1781: Nebst Bemerkungen über Gelehrsamkeit, Industrie, Religion und Sitten (Berlin and Stettin: [s. n.], 1784), 3: 559.

20 Wolfram Tuschner, "Von den Linzer Tänzen zum Wiener Walzer: Landler - Deutsche - Harbe Tanz,” Oberösterreichische Heimatblätter 46, no. 2 (1992): 220.

21 Rotation, for example, was mentioned as early as 1569 by Florian Daul in his polemical treatise. Florian Daul von Fürstenberg, Tantzteuffel: Das ist/ wider den leichtfertigen/ vnuerschempten Welt tantz/ wnd sonderlich wider die Gottß zucht ond ehrvergessene Nachttäntze (Frankfurt am Main: Martin Lechler, 1569), facsimile, ed. Kurt Petermann (München: Heimeran, 1978), fols. 22r, 37v, $91 \mathrm{r}, 101 \mathrm{r}$, and 106v. 
in the sources under both names. Although the Deutsche were probably already often danced as waltzes in the final phase of their existence, it is important not to be tempted by simplistic explanations of this complex historical phenomenon. ${ }^{22}$

The question of whether the Deutscher originated in the countryside or in the bourgeois environment is answered by scholars in various ways. ${ }^{23} \mathrm{Witz}-$ mann believes that it developed in Vienna and spread from there to the countryside, where it is still locally preserved in a fairly intact form. ${ }^{24}$ The bourgeoisie by no means invented the dance, but they gave it a representative and socially acceptable form for the urban way of life.

What has been repeatedly overlooked in the research is that the Deutscher phenomenon may also be perceived as a response by German-speaking countries, especially Austria, to the French minuet. It was in the decade following the French Revolution that Franco-Austrian relations became more tense, reaching an all-time low during the War of the First Coalition (1792-1797). The period of the Napoleonic Wars also saw a rise in patriotism in Austria, reflected not least in the popularity of the German Dance. ${ }^{25}$ To a certain extent, the Deutscher as a musical form takes its cue from the minuet, adopting the trio as its most obvious element.

The first printed sets of German Dances began appearing in Viennese publishing houses in the 1780s, the earliest being published by Christoph Torricella (from 1782 onwards), while performances of German Dances at Carnival balls in the Redoutensäle at the Vienna Hofburg are mentioned at least as early as the mid-1770s ${ }^{26} \mathrm{~A}$ look at the advertisements for printed music of Viennese publishers shows individual variations from publisher to publisher, but the trends regarding dance music on offer are clear: the Deutscher-waltz relationship is still dominated by the former in the first decade of the nineteenth century. After the Congress of Vienna, the ratio reverses in favour of the waltz. This is true, for example, of the publishing houses of Artaria and Giovanni Cappi (see Figures 1-2), ${ }^{27}$ but not, for instance, of the publisher Sigmund Anton Steiner, where the Deutscher and the waltz were more equally represented at least until the end of the 1820s. Viennese publishers served the entire market of the Austrian Empire and therefore did not necessarily reflect the situation of the city. The earliest

Witzmann, "Der sogenannte 'Deutsche Tanz',"102.

Peter Petersen argues that the origins of the Deutscher are to be found in the countryside. Peter Petersen, "Nochmals zum Tanz-Quodlibet im ersten Akt-Finale des Don Giovanni," Archiv für Musikwissenschaft 65, no. 1 (2008): 3.

Witzmann, “Der sogenannte 'Deutsche Tanz," 108.

Tuschner, “Von den Linzer Tänzen,” 221.

Günter Thomas, Studien zu Haydns Tanzmusik," Haydn-Studien 3, no. 1 (1963): 9.

The data are based on Alexander Weinmann, Vollständiges Verlagsverzeichnis Artaria \& Comp., Beiträge zur Geschichte des Alt-Wiener Musikverlages 2, vol. 2 (Wien: Musikverlag Ludwig Krenn, 1985); Alexander Weinmann, Verlagsverzeichnis Giovanni Cappi bis A. O. Witzendorf, Beiträge zur Geschichte des Alt-Wiener Musikverlages 2, vol. 11 (Wien: Universal Edition, 1967). 
independent waltzes were not offered by Viennese publishers until the first years of the nineteenth century. The popularity of the waltz continued to grow in $\mathrm{Vi}$ enna at least until the end of the 1820s, reaching its first peak with the appearance of the Tanzkapellen of Joseph Lanner and Johann Strauss. It was only at this time that the Deutscher really disappeared from the dance and musical culture of Vienna. In the cities on the periphery of the Empire, including Ljubljana, its presence was established and its popularity grew only once it had begun its decline in Vienna, never subsiding until the early 1830s.

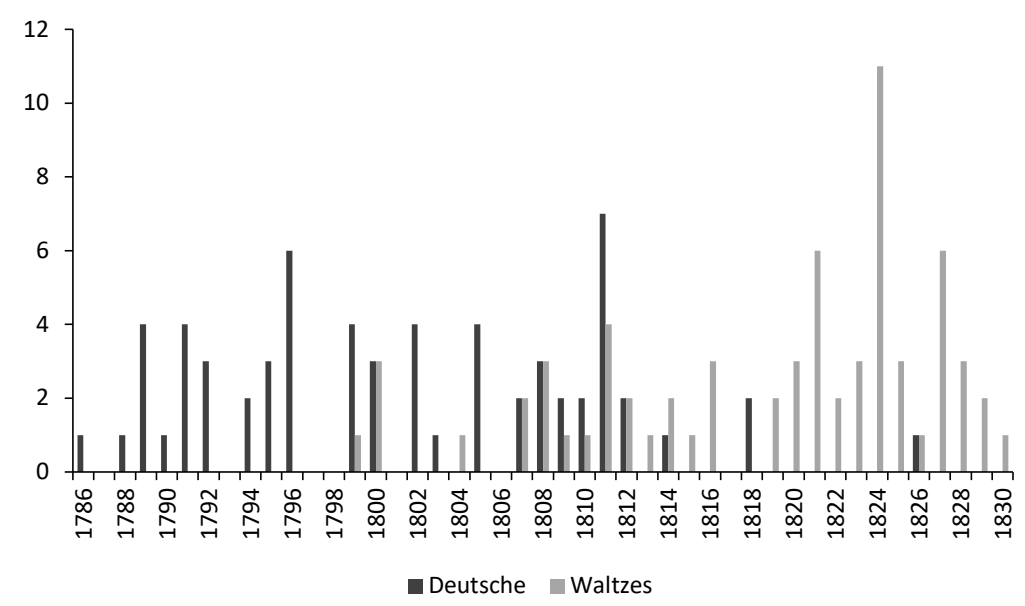

Figure 1: Music editions of Deutsche and waltzes published by Artaria \& Comp. in Vienna (1786-1830).

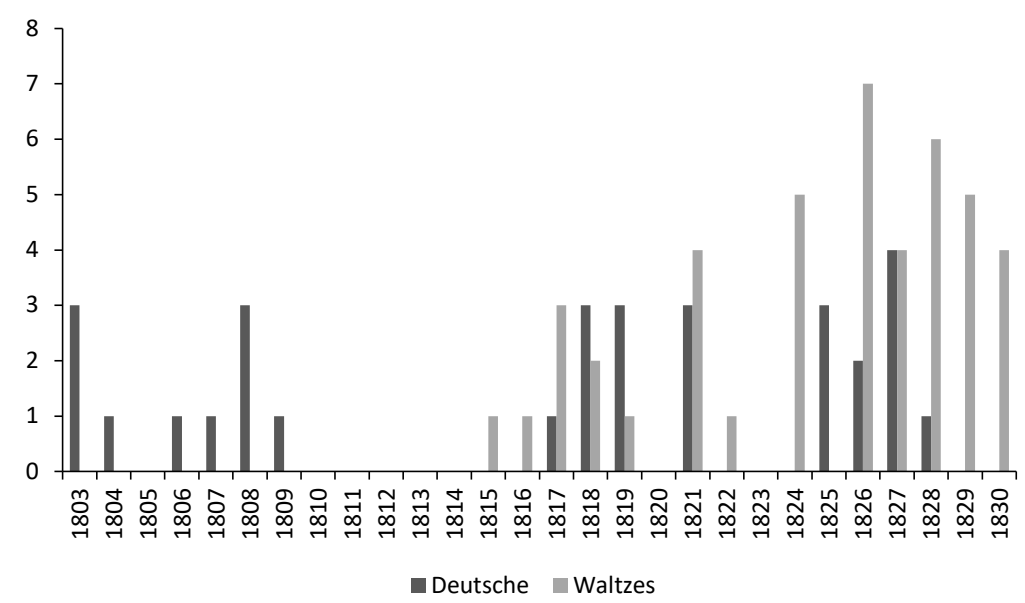

Figure 2: Number of sheet music editions of Deutsche and waltzes published by Giovanni Cappi in Vienna (1803-1830). 


\section{The Deutscher during and after the Congress of Laibach}

At the beginning of the nineteenth century, Ljubljana was a town on the outer limits of the Austrian Empire. The biting remark by the soon-to-be Chancellor Metternich, who at the beginning of his presence at the Congress of Laibach in January 1821 described the town as the front room of a comfortable apartment, is understandable from the perspective of a prince accustomed to the bustling pulse of Vienna, ${ }^{28}$ but nevertheless, social life in Ljubljana was not exactly desolate. There is no doubt that during the Congress of the Holy Alliance in 1821, Ljubljana came alive as never before, and virtually overnight, became the centre of Europe, at least for a few months. The young financial clerk Heinrich Costa, later to become a famous figure of Ljubljana's social and political life, began his Congress diary with the words:

The history of Carniola has seen many shining moments, but the chronicles do not show a time matching that of the first five months of the eternally memorable year 1821, in which by the grace and mercy of the most benevolent monarch the greatest men of their century were gathered in the most important affairs of state in the capital of Carniola. ${ }^{29}$

From 10 January to 22 May 1821, the Congress of Laibach brought together Emperor Francis I of Austria, Tsar Alexander I of Russia, King Ferdinand of Naples, Francis IV, Duke of Modena, and diplomats from various countries, together with a large entourage. The congress was directed and coordinated by Prince Klemens Wenzel Lothar von Metternich. Similarly to the Congress of Vienna in 1814, Ljubljana offered the diplomats, visitors, and locals a rich array of social events, including balls, concerts, and opera performances. Operas were almost exclusively devoted to the works of Gioachino Rossini, who, after the premiere of his The Barber of Seville in 1816, went on to take Europe by storm. In addition to this very opera, the Ljubljana Theatre, with the Italian singers of Antonio Cuniberti's opera company, also offered Rossini's L'inganno felice, L'Italiana in Algeri, La Cenerentola, and Eduardo e Cristina. ${ }^{30}$ On 26 March, his opera Othello was staged in German. Furthermore, several concerts (known as academies) of the Philharmonic

28 "Laibach ist gleichsam die Antichambre eines confortablen Appartements," in Aus Metternich's nachgelassenen Papieren: Friedens-Aera 1816-1848, eds. Richard Metternich-Winneburg and Alfons v. Klinkowström (Wien: Wilhelm Braunmüller, 1882), 3: 421.

29 "Die Geschichte Krains hat wohl der Glanzpunkte viel, aber eine Zeit wie die der ersten fünf Monathe des ewig denkwürdigen Jahres 1821, in welchen die Huld und Gnade des allergütigsten Monarchen die größten Männer ihres Jahrhunderts, und in den wichtigsten Staatsangelegenheiten in der Hauptstadt Krains versammelte, haben die Jahrbücher nicht aufzuweisen.” Eva Holz, Ljubljanski kongres 1821 (Ljubljana: Nova revija, 1997), 157.

30 Jože Sivec, "Rossinijeve opere na odru Stanovskega gledališča v Ljubljani," Muzikološki zbornik 1 (1965): 40-47. 
Society ${ }^{31}$ as well as numerous dance events were hosted in Ljubljana during the Congress, as this happened to coincide with Carnival season, always a livelier period in the city's social life.

During the Congress, a number of dance events took place in the Redoutensaal of Ljubljana, although Costa only mentions a few of them explicitly in his diary. ${ }^{32}$ Metternich's oft-quoted citation of the remark, which he had heard as early as mid-January, namely that dance events in Ljubljana were boring, should certainly not be taken literally. ${ }^{33}$ After all, sources testify to Metternich himself having danced a Polonaise in the company of ministers, deputies and other members of the diplomatic corps at a gala ball in the Redoutensaal on 25 February $1821.3^{34}$

The mere presence of the imperial couple in Ljubljana over a period of several months instilled new confidence in the established socio-political order and strengthened the loyalty of the inhabitants to the monarchy. The repressive and authoritarian political stance and the attempt to impose stability are clearly reflected in the words with which Emperor Francis I is said to have addressed the professors of Ljubljana's educational institutions during his visit:

\section{Stick to the old, for it is good; and our ancestors did well by it, why should we not? There are new ideas in the air now, which I cannot and never will ap- prove. Abstain from these, and stick to the positive; for I do not need scholars,}

31 See Primož Kuret, "Kongresno leto 1821 in Gašpar Mašek," in Maškov zbornik, ed. Edo Škulj (Ljubljana: Družina, 2002), 27-39.

32 Soirées dansantes on 29 January, 5 and 20 February and Freiball on 25 February 1821, for which 650 tickets were reportedly sold. Holz, Ljubljanski kongres, 164, 166-167, and 170-171.

33 "We even have public entertainments, such as two masquerade balls a week, the first of which, it is said, was not very amusing; among forty-five men there was a woman who had fallen asleep in a corner of the hall, which does not do much credit to the gallantry of those gentlemen." "Wir haben sogar öffentliche Vergnügungen, wie z. B. zwei Maskenbälle in der Woche, deren erster, wie man behauptet, nicht sehr lustig war; unter fünfundvierzig Männern befand sich eine Frau, die in einer Ecke des Saales eingeschlafen war, was die Galanterie jener Herren nicht viel Ehre macht.") Metternich-Winneburg and Klinkowström, Aus Metternich's nachgelassenen Papieren, 425.

34 "The ball was very splendid; all the high lords and ministers present, with the sole exception of the sovereigns, glorified the ball. It was truly a most delightful sight to see all the high lords in festive attire, adorned with their decorations, and no less pleasing was the cheerfulness that prevailed at the ball and the condescension with which the distinguished guests anticipated the citizens of the city. Almost all the ministers, envoys and other present diplomatic persons, even Prince Metternich, joined in a Polonaise." "Der Freiball fiel sehr glänzend aus; alle anwesenden hohen Herrschaften und Minister, mit einziger Ausnahme der Souveraine, verherrlichten den Ball. Es war wahrlich ein hochentzückender Anblick, alle die hohen Herrn in festlicher Kleidung, mit ihren Ordenzeichen behangen, zu sehen, und nicht minder erfreulich war der Frohsinn, der auf dem Balle herrschte, und die Herablassung, mit welcher die hohen Gäste den Bürgern der Stadt zuvor kammen. Fast alle Minister, Gesandte und die übrigen gegenwärtigen diplomatischen Personen, ja selbst Fürst Metternich, danzten eine Polonaise mit.") Holz, Ljubljanski kongres, 171. 
but good, righteous citizens. It is not for you to approve of the youth. Whoever serves me must teach what I command; whoever cannot do so, or comes to me with new ideas, he can leave, or I will remove him. ${ }^{35}$

These words may not be authentic, but they nevertheless clearly reflect the spirit of the attitude of the monarchical authorities of the time, which, since the French Revolution and the defeat of Napoleon, had been trying to re-establish and consolidate the old political order. Which of the social dances, apart from the Deutscher - the German national dance - could better express the political ideas of the time? The consolidation of Austrian national consciousness is thus reflected in dance, especially among the population on the periphery of the Empire. While the waltz was still considered a fairly new dance craze, the French Quadrille had been pushed aside and the French minuet had long been losing its former glory: from this point of view, it is not surprising that it was the Deutscher that became the most widely represented in the 1820s and, at least for a decade after the Congress, the most popular dance of social events.

Unfortunately, the dance schedules of the public dance events during the Congress of Laibach have not been preserved or remain undiscovered. From the advertisements of the composer Caspar Maschek (Gašper Mašek) in the Laibacher Zeitung, it is possible to glean a rough idea of the repertoire played at dance events. In fact, Maschek offered in his piano scores the very music for the dances that resounded in the ballrooms during the Congress. First, he cites four sets of Deutsche Tänze, adapted from themes from Rossini's Il barbiere di Siviglia (The Barber of Seville), a work that had just been staged in Ljubljana, and La gazza ladra (The Thieving Magpie). The advertisement is followed by a series of fashionable dances, mostly group dances: waltz, Monferine, Polonaise, Contradanse, Mazur, Cotillon, Ecossaise and Tempête.

35 "Halten Sie sich übrigens an das Alte; denn dieses ist gut; und unsere Vorfahren haben sich dabei gut befunden, warum sollten wir es nicht? Es sind jetzt neue Ideen im Schwung, die ich nicht billigen kan und nie billigen werde. Enthalten Sie sich von diesen, und halten Sie sich an das Positive; denn ich brauche keine Gelehrte, sondern brave, rechtschaffene Bürger. Die Jugend zu solchen zu billigen, liegt Ihnen ab. Wer mir dient, muß lehren, was ich befehle; wer dis nicht thun kann, oder mir mit neuen Ideen kommt, der kann gehen, oder Ich werde ihn entfernen." Allgemeine Zeitung [München], February 7, 1821, 152. See also Andrej Rahten, Gregor Antoličič, and Oskar Mulej, eds., Ljubljanski kongres 1821: Diplomatska študija Vladimirja Šenka - znanstvenokritična izdaja, Studia diplomatica Slovenica, Monographiae 5 (Celovec [Klagenfurt], Ljubljana, and Dunaj [Wien]: Mohorjeva založba, 2020), 14. 
S? u i i i l i e $n=\Re$ a d) $r$ i d) t.

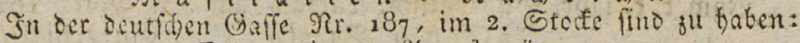

(5) i a v i e $r=24 u z ; \ddot{u} g e$

aller sänge, melthe in der (Samevals. Beit mäbreno deb (Songreff飞 in Laibad), im Tabre 822 aufgefübrt rouroen, uno zwar:

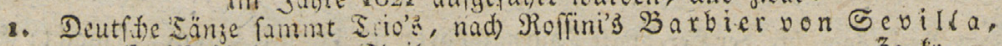

2. Detto

$3 . \quad$ Detto

1. 'Ibeil

Detto 3.

4. Deutfbe Einje auš :

5. Mibuliet uno Jionfrain

6. Polenaife uno Sontritang

7. y)iafur uno (5orillon

8. Drib (Eccofaifes uno Sampetes

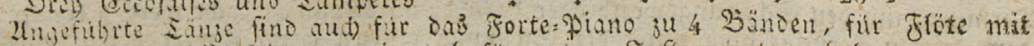

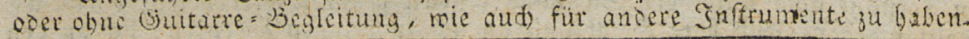

Figure 3: A selection of dance pieces by Caspar Maschek in Intelligenzblatt zur Laibacher Zeitung. ${ }^{36}$

Although the Deutscher was already known in Ljubljana before the Congress, composers had not yet named pieces written before 1821 Laibacher. ${ }^{37}$ The earliest Deutsche from the Music Collection of the National and University Library (Narodna in univerzitetna knjižnica - NUK) in Ljubljana are anonymous. The oldest example, probably dating back to the end of the eighteenth century, consists of a set of twelve Deutsche with trios and is preserved in an undated manuscript and simply called Teütsche. ${ }^{38}$ These are followed by Wienner Deutsche and Grazerische Deutsche from 1808..$^{39}$ The Wienner Deutsche is a set of five and the Grazerische Deutsche is a set of twelve anonymous Deutsche with trios. Another set of seven anonymous Deutsche with trios from $1809,{ }^{40}$ called Redout-Deutsche, has survived. A further set of six Deutsche für das Piano-Forte, worthy of comparison with Franz Schubert's German Dances, is among the

36 Intelligenzblatt zur Laibacher Zeitung, no. 26, March 30, 1821, 410. Digital Library of Slovenia, dLib.si, with kind permission.

37 Among the earliest compositions are probably the extant manuscripts 6 Redout Deutsche by Valentin Clementschitsch, Slovenian Klemenčič (see Appendix 2, no. 9). The manuscript cannot be precisely dated and the identity of the composer remains unclear. It is certain that he was a citizen of Ljubljana and a member of the Philharmonic Society from 1817 to 1823. See Nataša Cigoj Krstulović, "Posvetila na skladbah kot izhodišče za razpoznavanje kulturne zgodovine 19. stoletja na Slovenskem," Kronika 56, no. 3 (2008): 476. A set of Deutsche by Martin Schuller has been preserved under the title Redoutt Deutsche für's Piano Forte, NUK, Music Collection. In a piano arrangement by the oboist Wenzel Setwin, the same collection holds Redout Deutsche mit Introduzion, Trios und Coda von J. Bapt. Schiedermayer, uebersetzt für das Piano Forte von Wenzel Setwin, Hoboist. Johann Baptist Schiedermayr is recognised as the composer of several sets of Deutsche for the Ständischer National Redouten-Saal in Linz. The NUK Music Collection also holds an undated print of his VIII neue Deutsche für das Piano-Forte, Op. 48, from the publishing house of Cajetan Haslinger in Linz.

38 Teütsche für Clavi Cembalo, NUK, Music Collection.

39 Wienner Deutsche (1808); Grazerische Deutsche (1808), NUK, Music Collection.

40 Redout-Deutsche von Jabr 809 für das Piano Forte, NUK, Music Collection. 
earliest surviving compositions of this kind. ${ }^{41}$ For the violin part alone, the Deutsche vom Jahre 1807 in a set of twelve, ${ }^{42}$ a set of eleven with coda named Linzer Deutsche and a set of nine entitled simply Deutsche have been preserved. Two sets of Deutsche by Carl Handschuh, Kapellmeister of the Reuss von Plauen Seventeenth Infantry Regiment, stationed in Ljubljana, date from 1819. ${ }^{43}$ They were arranged for the piano by the oboist Wenzel Setwin, who was probably active in this Militärkapelle. ${ }^{44}$ Handschuh may have intended his compositions for dances hosted for the military.

The year 1821 was a turning point for the Laibacher Deutscher. The surviving musical sources show beyond doubt that the awareness of belonging to the city only matured during and after the Congress. From then on, advertisements for printed and manuscript sets of dance music appeared regularly in the newspapers, and by the early 1830s it was the Deutsche that dominated among them. Interestingly, the first set of the so-called Laibacher Deutsche to be offered on the music market was actually by the composer Ferdinand Kauer, who, according to the available information, did not even visit Ljubljana but was active in Vienna. What is even more unusual is that in this case it is not a musical print, but manuscript copies that the composer offered to interested parties in his apartment in Josefstadt, then still a suburb of Vienna (see Appendix 2, no. 12). Were these dances intended for performances in Ljubljana, or did the Congress serve as a trigger, heightening Vienna's interest in Ljubljana?

Among the approximately fifteen composers, some foreign but mostly local, whose work contributed to this dance-musical form, Caspar Maschek's prominence was facilitated by his theatrical background. Maschek, who had moved to Ljubljana from Prague via Bratislava (Preßburg) and Graz, arrived in Ljubljana as Kapellmeister of the Estates Theatre at the beginning of the 1820/21 opera season, just a few months before the start of the Congress. Most of his

41 A comparison of the incipits in the RISM online catalogue revealed the authorship of Karol Scholl (1778-1854) in connection with his set of twelve Deutsche entitled Balli Tedeschi per il Piano Forte a quadro mani of 1809 (RISM ID no. 550402397). The Ljubljana transcription is a selection of six Deutsche, but not in the original order.

42 Part of a composite manuscript marked “A. W. Mozart, Walzer," NUK, Music Collection.

43 The presence of Carl Handschuh in Ljubljana is demonstrated by a vocal and instrumental concert given by the Philharmonic Society on 18 December 1818 under his direction. Dragotin Cvetko, Zgodovina glasbene umetnosti na Slovenskem (Ljubljana: Državna založba Slovenije, 1959), 2:169. On the concert sheet still preserved, the composer is named as "Kapellmeister des hier garnisonirenden löblich. K. K. Infanterie-Regiments Fürst Reuß-Plauen,” NUK, Music Collection, Philharmonic Society Archive, concert leaflets.

44 NUK, Music Collection holds: Redout Deutschen Für das Carneval 1819: Componirt von Carl Handschuh, Kapellmeister löbl. k. k. Prinz Reus Blauen [sic] Inf. R[e]gim[en]t; Uibersetzt für daß Piano Forte von Wenzl Setwin Hoboist mp; and further Redout Deutsche pro Anno 1819: Componirt von Carl Handschub Kapellmeister bey löbl. k. k. Prinz Reus Blauen [sic] Inf. R[e]gim[en]t; Uibersetzt für daß Piano Forte von Wenzl Setwin Hoboist mp. Another undated manuscript entitled Redoutt Deutsche fürs Piano-Forte von Carl Handschub is preserved in the same collection. The unknown copyist of this manuscript is also the author of the identically titled manuscript Redoutt Deutsche by Martin Schuller. 
dances are adaptations of operatic songs, mostly from Rossini's operas. ${ }^{45}$ The mention of this famous opera composer, and featuring him on the covers of Deutsche, can be interpreted as a distinct marketing ploy to increase profitability. ${ }^{46}$

Unlike other composers, Maschek did not publish his dances in print, but supplied the local music market with transcriptions, apparently employing professional copyists. He did not offer exclusively his own compositions in advertisements, but also works by other composers. ${ }^{47}$

While most of the surviving or now only attested sets of Deutsche were intended for dance events in the Redoutensaal, the Estates Theatre, or at the Laibacher Scbießstätte (Ljubljana Shooting Range), they were also performed regularly during intermissions of operas and theatre performances. ${ }^{48}$ That this was not just a short-lived phenomenon is also shown by the record of the performance schedule at the Estates Theatre as late as 14 January 1836: "During intermissions, new Redout-Deutsche are performed by the entire orchestra." ${ }^{49}$ It seems that the performances served as a kind of background music and entertainment in the theatre and, of course, also as a promotion of the latest fashionable dances and their composers. Despite the oddity, such performances between the acts of theatre plays were not entirely unique in Ljubljana and were at least occasionally mentioned in other cities as well. ${ }^{50}$

45 Il Barbiere di Sevilla (1821), La gazza ladra (1821), La Cenerentola (1822), Eduardo e Cristina (1822), Zelmira (1823). In addition to the set with adaptations from Rossini's operas, further two sets of Maschek's Deutsche have been documented: Il Crociato in Egitto (1825) and Fra Diavolo (1832). Il Crociato in Egitto by Giacomo Meyerbeer was first performed in Ljubljana only a few years after the publication of the Deutsche, namely in January 1830 . The opera Fra Diavolo by D.-F.-E. Auber, however, saw a record number of performances in Ljubljana in the 1831/32 season. See Jože Sivec, Opera na ljubljanskih odrih od klasicizma do 20. stoletja: Izbrana poglavja, eds. Metoda Kokole and Klemen Grabnar (Ljubljana: Založba ZRC, ZRC SAZU, 2010), 80-81 and 106. Of Maschek's named compositions, only the Deutsche Tänze aus Rossini's Eduard und Christine für den Carneval 1822, NUK, Music Collection, has survived (see Appendix 2, nos. 13, 15, 16, 22, 30, and 55).

46 See Emily H. Green, Dedicating Music, 1785-1850 (Rochester: University of Rochester Press, 2019), 160-168.

47 Maschek offered Deutsche by the following composers in his advertisements: D. Weber (Deutsche based on the opera Don Juan, 1822; probably Mozart's Don Giovanni, performed in Ljubljana in the 1821/22 season), a set of the so-called Glöckerl-Deutsche, by a certain K. W. S. (1822); Eduard Hysel's Deutsche (1822), and two sets by Joseph Wilde after the operas La Molinara (G. Paisiello, 1822) and Freischütz (C. M. von Weber, 1822). See Appendix 2, nos. 15-16.

48 Such performances are recorded regularly in the so-called 'Comedien-Zettel Sammlung', kept in the National Museum of Slovenia in Ljubljana (hereafter referred to as NMS), shelf-mark III 13085. See Appendix 2, nos. 1-8, 16, 17, 23, 24, 26, 28, 29, 31, 34, 39, 41, 43, 54, and 57-60.

49 "In den Zwischenakten werden neue Redout-Deutsche vom sämmtlichen Orchester-Personale aufgeführt werden.” NMS, Comedien-Zettel Sammlung, 1835/36, January 14, 1836.

50 For example, at the Estates Theatre in Klagenfurt German Dances by the Kapellmeister Görgl, the violinist Alois Merk and, lastly, a certain actor and singer, Miller, were performed during intermissions of theatre plays on January 7,14, and 16,1830. Merk's "Cotillons" (eigentlich Deutsche) were reportedly performed with full orchestra. Carinthia: Zeitschrift für Vaterlandskunde, Belehrung und Unterhaltung, no. 3, January 16, 1830, 16, and ibid., no. 4, January 23, 1830, 20. In Graz in January 1826 a performance of Höfners Redout-Deutsche in the Estates Theatre at the end of the play is mentioned. Steyermärkisches Intelligenzblatt zur Grazer Zeitung, no. 9, January 16, and no. 10, January 17, 1826. 
In Ljubljana, apart from Maschek few other professional musicians composed Deutsche. Among these it is worth mentioning Leopold Ferdinand Schwerdt (c. 1770-1854), ${ }^{51}$ who composed dances between 1815 and 1828, and probably also much earlier than that, after his arrival in Ljubljana (c. 1806). In fact, only one undated set of six Deutsche by Schwerdt survives in manuscript, but it is not titled as Laibacher and lacks the designations Redout- or Schießstatt. ${ }^{52}$ In regard to their musical conception, these Schwerdt dances resemble the earlier Deutsche, and it is assumed that they were written for the Carnival dances (Theater-Bälle) at the Estates Theatre, or that they were also played there for self-promotional purposes between the acts of theatre performances. ${ }^{53}$

Another professional musician was Georg Micheuz (Jurij Mihevec) (18051882), who composed one of his first musical pieces in his sixteenth year at the time of the Congress of Laibach. ${ }^{54} \mathrm{He}$ contributed sets of six Deutsche for the 1824-1827 Carnival dance seasons at the Laibacher Schießstätte and also for the 1825 and 1826 seasons for the Laibacher Redoutensaal..$^{55}$ Meanwhile, Micheuz, already active in Vienna, published his Original Laibacher Schießstatt Deutsche for the year 1825 in the Lithographic Institute (Lithographisches Institut nächst der Burg), and in 1826 with the Vienna publisher Cappi \& Comp. The latter are dedicated to the then Mayor of Ljubljana, Johann Nepomuk Hradeczky, who was considered a supporter of the Ljubljana Shooting Range. ${ }^{56}$ The composer dedicated his VII neue Schießstatt-Deutsche, advertised in transcriptions, to the same person as early as 1824 . Micheuz regularly added the label Original to his compositions, perhaps to emphasise that they were original creations and that the dances did not include borrowed musical motifs from operas.

The majority of the Deutsche sets that have survived or have been documented come from the pens of amateur musicians, so-called dilettantes. Most of them were public officials from the nobility and the bourgeoisie. Some were active in one way or another in the Ljubljana Philharmonic Society. The first to be mentioned is the official Leopold Cajetan Ledenig (c. 1795-1857), who was most productive as a composer of Laibacher Deutsche exclusively for the Redoutensaal. His editions with sets of six dances are documented between

51 Zoran Krstulović, "Značilnosti kompozicijskega stavka L. F. Schwerdta s posebnim ozirom na njegove maše" (Masterthesis, Univerza v Ljubljani, 1998), 15-19.

52 Deutsche für das Piano Forte vom Schwerdt is part of a composite manuscript marked "W. A. Mozart, Walzer" in the NUK, Music Collection.

53 See Appendix 2, nos. 2, 17, 23, and 41.

54 Der beliebte Laibacher Congress Marsch: Bey Gelegenheit des im J. 1821 gehaltenen Congresses von dem löbl. k. k. Inf.-Regimente; Fürst Gustav Hohenlohe-Langenburg $N^{5} .17$ (ehmals Reuss von Plauen) aufgeführt; Componirt und für das Piano-Forte zu 4 Händen eingerichtet von Georg Michéuz. Wien: Pietro Mechetti qm Carlo, no. 1915 [c. 1829]. Another edition of this composition was published in Paris in 1851 under the title Marche militaire.

55 See Appendix 2, nos. 11, 27, 31, 34, and 37.

56 Cigoj Krstulović, "Posvetila na skladbah," 475. 
1823 and 1831, but only the 1824 edition (in manuscript) and three beautifully designed lithographs from the Graz publishers Johann Franz Kaiser and Ignaz Hofer $(1827,1828,1830)$ remain. The 1829 edition was marked by Ledenig as the eighth volume, the 1830 edition as the ninth volume and his last known set of Deutsche from 1831 as the eleventh volume. The latter should probably have been marked as the tenth volume. If this numbering is correct, Ledenig published the first volume as early as 1822 , but no mention of this has so far been found in the sources (see Figure 4). ${ }^{57}$

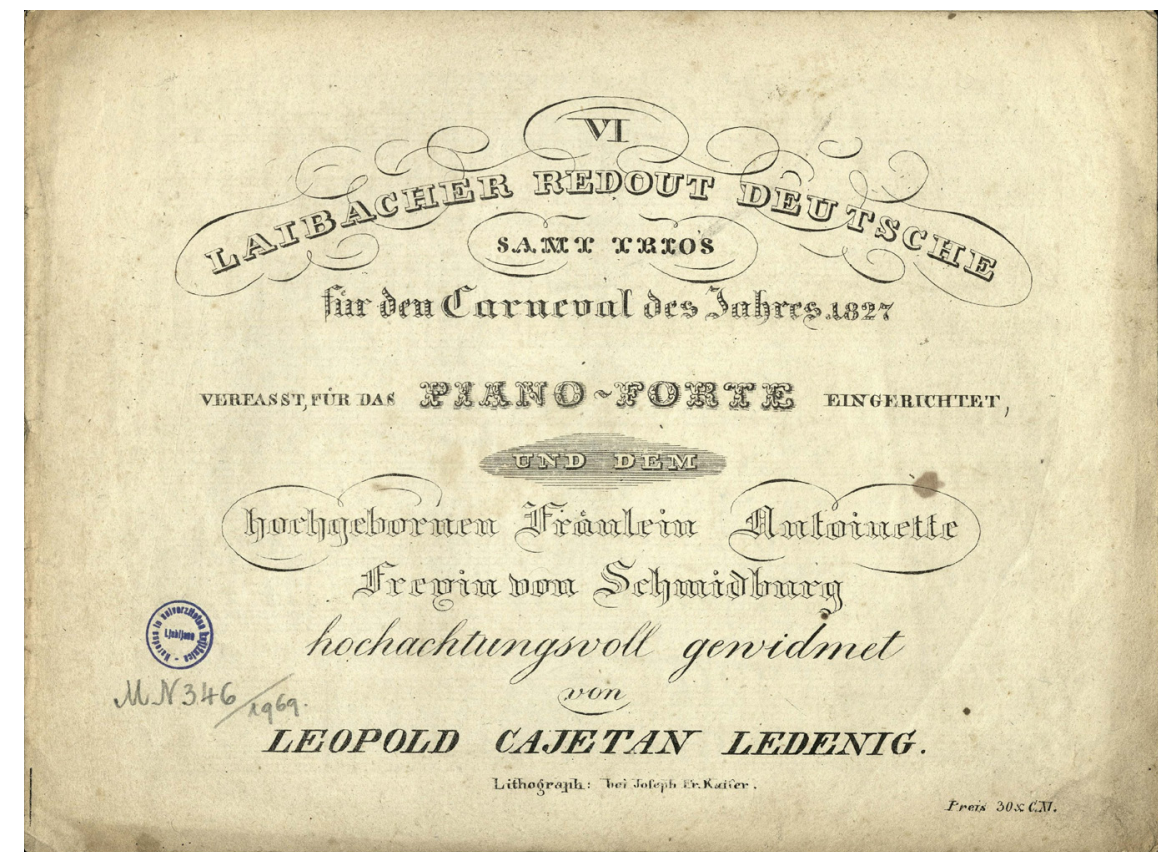

Figure 4: Leopold Cajetan Ledenig, VI Laibacher Redout-Deutsche samt Trios (1827), title page. ${ }^{58}$

Among the prolific composers of the Laibacher Deutsche was also Baron Louis (Ludwig) Lazarini, who contributed five volumes of Redout-Deutsche (1822-1825 and 1830) and two volumes of Schießstatt-Deutsche (1827 and 1830). ${ }^{59}$ Among the members of the extended Lazarini family, this baron has so far not been identified beyond doubt, but it was probably Ignaz Ludwig von Lazarini-Zobelsberg (1799-1888), active in Graz as "K. K. Kämmerer

59 See Appendix 2, nos. 14, 19, 20, 24, 28, 35, 48, and 57. 
und Gubernialsekretär" and the owner of estates in Carniola. Another possible match could be Ludwig von Lazarini-Jablanitz (1798-1856). ${ }^{60}$

Individual sets of Redout-Deutsche were also contributed by the clerk Franz Seraphin Nepozitek (1828), ${ }^{61}$ Carl Fischer von Wildensee (1828-1829), ${ }^{62}$ the commander and later Major in the Prince Hohenlohe Infantry Regiment, the public official Joseph Bosizio (1831), ${ }^{63}$ and in 1831 also the later Colonel Julius Fluck von Leidenkron (1813-1897). ${ }^{64}$

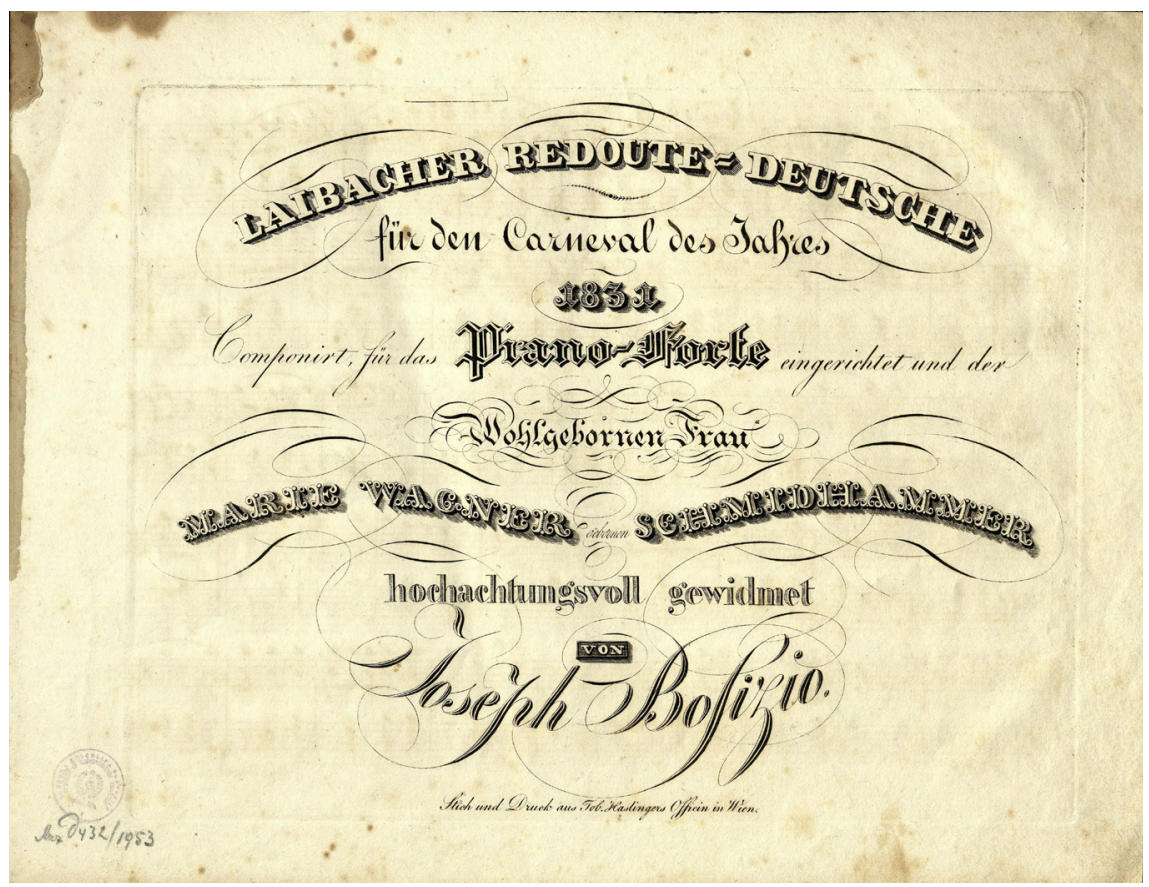

Figure 5: Joseph Bosizio, Laibacher Redout-Deutsche (1831), title page. ${ }^{65}$

60 Schematismus von Krain und Kärnten vom Jahre 1826 (Laibach: Leopold Eger, [1826]), 322; Gothaisches genealogisches Taschenbuch der Freiherrlichen Häuser (Gotha: Justus Perthes, 1911), 69: 529-533.

61 The advertisement of Nepozitek's set of Deutsche in the Intelligenzblatt zur Laibacher Zeitung, no. 17, February 9, 1828, 74 states: "Die von dem Herrn N_k hinterlassenen [...]" (see Appendix 2, no. 40). The word binterlassenen means that the composer died shortly before publication. For probably the same reason, it is mentioned that the proceeds of the sale go to charity.

62 See Appendix 2, nos. 38 and 44. Wildensee's set VI Laibacher Redout-Deutsche for the 1828 Carnival has been preserved in manuscript. NUK, Music Collection.

63 See Appendix 2, no. 51.

64 Appendix 2, no. 52; Miha Preinfalk, “Genealoška podoba rodbine Zois," Kronika 51, no. 1 (2003): 42.

65 Digital Library of Slovenia, dLib.si (with kind permission). 
Among the composers of Schießstatt-Deutsche, the names of Carl Suppantschitsch (Zupančič) (1826 and 1828) and S. T. Thomaschovitz (1829) also appear. ${ }^{66} \mathrm{~A}$ special feature worth mentioning is an advertisement in the Laibacher Zeitung in which the Ljubljana music merchant Leopold Paternolli offered, in addition to the Deutsche by Leopold Ferdinand Schwerdt, transcriptions of Carniolan dances in German style, namely 6 Krainer mit Trio's (im deutschen Styl) in editions for piano, two violins, two violins and bass, and for orchestra by a certain Joseph Schwerd. ${ }^{67}$

The question of whether the production of dance music in Ljubljana in the 1820s was in any way coordinated and whether the compositions of the Deutsche may have been commissioned by organisers of balls remains unclear due to the lack of sources. At least some of the sets were certainly created on the composers' own initiative, responding with their compositions to the demand and needs of the music market.

The surviving transcriptions and music publications of the Laibacher Deutsche often have artistically designed covers, most probably motivated by a desire to increase the representativeness and prestige of these publications. The dedications to certain persons or societies, be it the Ljubljana Hunters' Society or, more often, to ladies of the Ljubljana nobility and prominent bourgeoisie, also enhanced the significance of the sheet music editions. ${ }^{68}$ Their names occupy the most prominent and often the most carefully designed central part of the covers. The dedication may derive from a variety of personal inclinations of the composer or publisher, but it often also has a clearly identifiable commercial value. Dedications to amateurs and ladies - extremely common in dance music releases in particular - are not only a tribute to a chosen person, but also a signal to the public that the works are suited to the musical tastes and performance abilities of this most numerous commercially valuable target audience. At the same time, works with such dedications were a priori exempt from public critical scrutiny. ${ }^{69}$ By being chosen for dedication, the person to whom the work was dedicated in a sense also assumed responsibility for the quality and

66 See Appendix 2, nos. 33, 42, and 46. The Slovenian form of the surname Thomaschovitz is not entirely clear, probably it is Tomažovic. The Slovenian biographical lexicon mentions the composer Simon Tomaževec in a short entry, who is said to have worked in the Hofburgkapelle in Vienna and later in St. Petersburg. In any case, the composer published several Lieder and some dance compositions in Vienna around 1840 under the name S. T. Tomashoviz. His Gräfenberger Krisis-Polka, Op. 8, and a mention in the newspaper Oesterreichisches Morgenblatt 6, no. 132, November 4, 1841, 547, suggest that he was active in Gräfenberg (today Jeseník, Czech Republic). See “Tomaževec, Simon (1805-?),” Slovenska biografija (Ljubljana: Slovenska akademija znanosti in umetnosti, Znanstvenoraziskovalni center SAZU, 2013), accessed July 10, 2021, http://www. slovenska-biografija.si/oseba/sbi704239/\#slovenski-biografski-leksikon.

67 Intelligenzblatt zur Laibacher Zeitung, no. 6, January 15, 1828, [24].

68 The persons to whom the works are dedicated are described in more detail in Cigoj Krstulović, "Posvetila na skladbah," 474-481.

69 Green, Dedicating Music, 148. 
usefulness of the music, and at the same time the public was given the impression of a kind of review, as if the dedicatee had already heard and appraised the work before it was published (see Figure 5). ${ }^{70}$

The rather consistent labelling of the Deutsche as Redout- and Schießstatt-, in addition to naming the location of the ballroom, was also a way of showing the social affiliation of the creators, since the Redoutensaal was maintained by the Regional Estates of Carniola, while the Schießstätte was the domain of the city and its inhabitants. The Laibacher Redoute, built in 1784, had its premises on the site of a former Jesuit school building, ${ }^{71}$ which had been destroyed or at least badly damaged by fire a decade earlier. After 1786, a ballroom was erected in this building, and it was often also used to host concerts. ${ }^{72}$ The building of the Shooting Society (Schützenverein), the so-called Schießstätte, situated in the then suburb of Poljane below the castle hill, also provided a venue for dance events. ${ }^{73}$ The wooden building, dating back to 1737 , was replaced by a brick edifice in 1804, which also provided the members of the Schützenverein with first floor premises for the annual Carnival dances. The building remained in use until the last quarter of the nineteenth century. ${ }^{74}$ The organisation of the Carnival balls in the Redoutensaal was apparently the responsibility of the directorate of the Estates Theatre; alternately, balls were held at the theatre itself. ${ }^{75}$

In Ljubljana the Deutscher was already equated with the waltz in its final period. For example, there is an interesting case of lithographed Laibacher Redout-Deutsche (if this is indeed an identical source) listed in the pre-order advertisements for Julius Fluck's Deutsche from 1831, while the cover of the print reads Six Valses avec Trio. ${ }^{76}$ The last advertised set of Laibacher Deutsche from 1832 are also actually waltzes by Johann Strauss the Senior. His opuses 47, 48 and 49 were published in Vienna explicitly as waltzes, ${ }^{77}$ but were

70 Ibid., 153-154.

71 Today the Janez Lovec Centre on the Levstik Square. The building was removed after the Ljubljana earthquake in 1895.

72 Jože Suhadolnik, Stari trg, Gornji trg in Levstikov trg: Arbitekturni in zgodovinski oris mestnih predelov in objektor, lastniki his ter arbivsko gradivo Zgodovinskega arbiva Ljubljana (Ljubljana: Zgodovinski arhiv, 2003), 30-31.

73 The name Streliška ulica (Shooting Range Street) is still a reminder of the place today.

74 Peter von Radics,, Geschichte der Rohrschützen-Gesellschaft des k. k. priv. Landes-Hauptschießstandes Laibach unter dem hohen Protectorate Sr. k. k. Hoheit des durchlauchtigsten Herrn Erzherzogs Ernst: Festschrift zur 600jährigen Jubelfeier der Zugehörigkeit Krains zu Österreich (Laibach: Ig. V. Kleinmayr \& Fed. Bamberg, 1883), 12-18.

75 The usually six and occasionally up to eight masquerade balls per season in the theatre building and alternately in the Redoutensaal are documented by the preserved leaflets at the NMS (Comedien-Zettel Sammlung).

76 See Appendix 2, no. 52. The only surviving but unfortunately incomplete copy is held by NUK, Music Collection.

77 Max Schönherr and Karl Reinöhl, Johann Strauß Vater: Ein Werkverzeichnis (London, Wien, and Zürich: Universal Edition, 1954), 74-78. See also the advertisement in Appendix 2, no. 56. 
offered to the Ljubljana audience by the music dealer Paternolli as Laibacher Redout-Deutsche ${ }^{78}$ Strauss himself never used the title Deutscher for his dance compositions, preferring the name Walzer from the very beginning of his career. In the early 1830s, the Deutscher's popularity declined and it is mentioned less and less in the sources. For the 1833 Carnival season in Ljubljana, Paternolli offered only the latest waltzes by Strauss, Morelly, Lanner and Fahrbach. ${ }^{79}$ The fact that the dance label, at least, was retained in Ljubljana for a few more years is also proved by a record in the archives of the local theatre directorate, which still in the 1838/39 season listed copying costs for the new Deutsche among the accounts of the dance events. ${ }^{80}$

This looseness in naming is also evident in the examples which, even before 1821, refer to other related music and dance forms as Walzer. In the same handwriting as the two sets Redoutt Deutsche fürs Piano Forte by Carl Handschuh and Martin Schuller, ${ }^{81}$ two more examples have survived in the National and University Library in Ljubljana, which show a broad rather than a definite use of the designation. The anonymous set Walzer fürs Piano Forte with five waltzes, ${ }^{82}$ are most probably Ländler. The Strasburger Walzer fürs Piano Forte by the Kapellmeister Handschuh, however, is an interesting example of a set of five eight-bar melodies most reminiscent of the Steirische. ${ }^{83}$

Judging by the preserved music of the Laibacher Deutsche, they certainly cannot be equated with waltzes. A prominent and recognisable element of the representative bourgeois Deutscher for performances at public dance events is the trio, which is rarely found in the waltz. ${ }^{84}$ The set of dances Quatre valses, which Maschek intended for a soirée dansante in February 1829 are probably the earliest original set of Laibacher Walzer judging by their form without the added trios and by their more melodious phrasing. ${ }^{85}$

78 See Appendix 2, no. 56.

79 Amtsblatt zur Laibacher Zeitung, no. 9, January 19, 1833, 49.

80 “Copiatur neuer Deutschen," Archives of the Republic of Slovenia, AS 13. Višja gledališka direkcija v Ljubljani, Uibersicht Ball-Erträgnis 1838/39.

81 See footnote 44 .

82 The five anonymous waltzes are followed by a dance called Budschaner with a trio.

83 This may be the music that accompanied the typical dance figure of the Steirisch, the woman spinning below the man's arm, which is called the Strasbourg figure in earlier sources, including the above-mentioned work by Georg Link. The figure is also reminiscent of the reference to the "Obersteyrisch, mit ein und zwei Damen", which was advertised in 1828 by Scio, the dancing master of the Carniolan Provincial Estates. See Figure 4.

84 There are a few exceptions. In the second and third decades of the nineteenth century, waltzes with trios were occasionally published in Vienna, for example by Carl Steinacker (1811-1813), Josef Wilde (1816), Johann Peter Pixis (1818-1822), Johann Nepomuk Hummel (1821), Moritz von Dietrichstein (1825-1826), Josef Hüttenbrenner (c.1826), and Karl Stein (1828).

85 Quatre valses pour le piano-forte composées a l'occasion d'une soirée dansante le 8. Fevriér 1829, NUK, Music Collection. For more about this set of waltzes see Nataša Cigoj Krstulović, "Med sentimentom in razumom: K zgodovini in pomenu valčka za klavir v 19. stoletju na Slovenskem," Muzikološki zbornik 46, no. 2 (2010): 41-42. 
Sets of Deutsche are most often preserved in versions for piano, but the advertisements often mention other instruments (piano for four hands, string trio, orchestra, guitar, solo instruments with accompaniment). It is not possible to determine which of the versions are original and which are arrangements. The piano version has proved to be the most convenient and versatile, while the ensemble or orchestral versions have not been financially viable on the music market, neither for composers nor publishers. Dance and music lovers were often introduced to the latest dances at the piano in their home environment even before the start of the dance season. Dance music was not played on the piano for entertainment and leisure only. Sources often mention small dance gatherings with family and friends, ${ }^{86}$ where the company danced to the piano accompaniment. ${ }^{87}$

Although Deutsche are the most numerous of the surviving dance music from Ljubljana of the 1820s, this was certainly not the only popular dance of the time. At the annual public Carnival dances, an important addition to the evening was an entertaining dance game called Cotillion, performed to the music of the Ländler. For example, 13 Laibacher Redout Laendler zu Cottillions für das Piano Forte by Louis Lazarini, dedicated to the wellborn lady Wilhelmina Pruhl, have been preserved in manuscript in the National Library in Vienna. ${ }^{88}$ The National and University Library in Ljubljana, however, holds a transcription of the set 9 Landler $z u$ Cottillions by the same composer. ${ }^{89}$ Apart from Deutsche, it is the Ländler that are most frequently mentioned in newspaper advertisements for new dance music.

In 1828, the dancing master of the Carniolan Provincial Estates, Franz von Scio, published an advertisement in the Laibacher Zeitung inviting the nobility,

86 Heinrich Costa wrote in his diary on 29 February 1824: "Today there are many private balls, hosted by Baron Zois, Oblack, Hoinig, Gelbling etc., then there is a closed society of 70 people at the Kircker's, also today there is the usual ball at the theatre, which starts at 7 o'clock." Cornelia Schollmayr-Costa, "Alte Tagebücher," Laibacher Zeitung 111, no. 121, May 28, 1892, 1033-1034. See also Holz, Ljubljanski kongres, 125. On 23 January 1828, Valentin Češko also wrote a letter from Prague to his sister and a prominent Ljubljana lady, Jožefina Terpinc, asking her which dances were currently being danced most widely in Ljubljana. He assumes that the Terpincs will continue to hold small dance meetings this year, as they have a large room at their disposal: "What kind of dances are being danced at present in Ljubljana? You will probably also give a little dance entertainment this year, since you have a large room. How sorry I am not to be able to be there." Nataša Budna Kodrič, Korespondenca Jožefine in Fidelija Terpinc (1825-1858), Objava arhivskih virov 41 (Ljubljana: Arhivsko društvo Slovenije, 2018), 145.

87 Even for public dance events organised in 1835 by the then still young Ljubljana Casino (founded in 1834), there are reports of dancing with piano accompaniment. Cf. Walter Šmid, "Aus Alt Laibach," Carniola: Mitteilungen des Musealvereins für Krain 2, nos. 3-4 (1909): 149.

88 Österreichische Nationalbibliothek, Musiksammlung (A-Wn), L18. Kaldeck Mus.Hs.23622. The cover bears the name of the copyist Kestler mp. and the former owners Tiny and Elise Lehn. The series of thirteen Ländler is completed by the Einzugs-Galopp by Johann Strauss, Op. 35, notated on the reverse of the manuscript. The piece by Strauss was published by Tobias Haslinger in Vienna in September 1830, which can therefore be considered the terminus post quem of Lazarini's Ländler. Schönherr and Reinöhl, Johann Strauß Vater, 56.

899 Landler zu Cottillions für's Pianoforte mit Begleitung einer Violine componirt und gewidmet der Hochwohlgebohrnen Baronesse Cecille von Lichtenberg, gebornen Baronesse von Billichgratz, Sternkreutz Ordensdame von Baron Louis Lazzarini, NUK, Music Collection. The violin part is not preserved. 
military personnel and prominent citizens of Ljubljana to take dancing lessons. ${ }^{90}$ It is rather strange that among the various forms of minuet and types of group dances, he also offered lessons in "Deutsch oder Walzer," since the Deutscher hardly appears elsewhere in the dancing masters' syllabuses. It is not entirely clear from the advertisement whether two different dances are meant, or whether Scio had already equated Deutscher and waltz in 1828 . The other dances in this offer show that the dance repertoire at the end of the 1820 s was quite varied and extensive. Also interesting is Scio's later advertisement for dance lessons in 1839, in which he still places the minuet first. This is followed by the "Walzer auf drei und zwei Schritte," whereas the Deutscher disappeared from the list. In 1839, Scio also offers the Steyrisch, while in 1828 he lists the "Obersteyrisch, mit ein und zwei Damen."

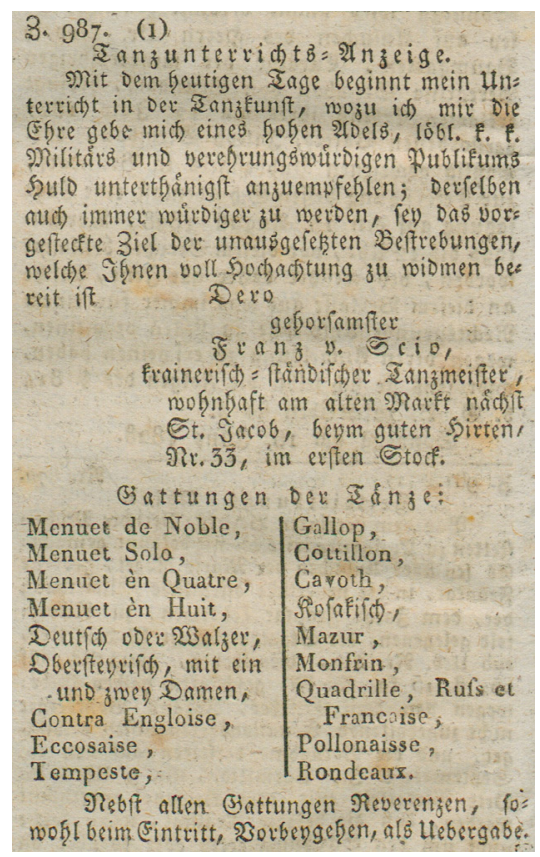

Figure 6: Advertisement for dance lessons by the dancing master of the Carniolan Provincial Estates Franz von Scio in Amtsblatt zur Laibacher Zeitung. ${ }^{92}$

90 See Figure 6. In 1830, Marie Börnstein, a visiting actress and dance teacher in Ljubljana, advertised ballroom dance classes for children and young women in twenty lessons, including the Deutsch, Mazur, Ecossaise, Galoppe, Monferine, Quadrille, Tempête, Menuette, and Gavotte. NMS, Comedien-Zettel Sammlung, 1830/31, October 2, 1830; October 3, 1830.

91 Intelligenzblatt zur Laibacher Zeitung, no. 135 [recte no. 144], November 30,1839, 912. More on both advertisements Lidija Podlesnik Tomášikova, "Plesni mojstri Kranjskih deželnih stanov v 18. in 19. stoletju," Muzikoloskki zbornik 47, no. 1 (2011): 129-130, https://doi.org/10.4312/mz.47.1.113-140.

92 Amtsblatt zur Laibacher Zeitung, no. 94, August 5, 1828, 716. Digital Library of Slovenia, dLib.si, with kind permission. 


\section{A Digression: the Deutscher in Graz}

The appearance of the Deutscher in Ljubljana in the 1820s is not unique within the Austrian Empire at that time. While the dance had long ceased to attract much interest in Vienna, it enjoyed a similar popularity in neighbouring Graz, Klagenfurt and probably elsewhere. While the situation in these towns needs to be studied in more detail, a brief glance at the sources shows that performances of Deutsche by local artists at the annual Carnival balls in Graz predate Ljubljana by several years. The Grazer Zeitung began to publish advertisements for new sheet music editions on a regular basis no later than 1815 . Given the geographical proximity and the close sociocultural contacts between the capitals of Styria and Carniola, it seems likely that this fashion came to Ljubljana from Graz. The fact that a considerable number of editions of the Laibacher Deutsche were printed by the Graz lithographer Joseph Franz Kaiser also testifies to the contacts between the two cities.

One may conclude that the contemporaries in Ljubljana were very familiar with the dance music of Graz and the fashion trends there. Nataša Cigoj Krstulović has already pointed out that Maschek moved to Ljubljana from Graz, where he met the already established and popular Deutsche. ${ }^{93}$ From time to time, advertisements for sheet music of the Grazer Deutsche appear in the Laibacher Zeitung. ${ }^{94}$ Among the most prolific composers of the Deutsche for the Redoutensaal and Casino in Graz were Eduard Hysel (1770-1841), ${ }^{95}$ the director of the Graz Theatre, and the priest Martin Schuller. ${ }^{96}$ Their sets of the Grazer Deutsche were also sold and copied in Ljubljana. The printing of

93 Cigoj Krstulović, "Med sentimentom in razumom," 40.

94 The bookseller Paternolli repeatedly offered Grazer Deutsche in Ljubljana at the end of the 1820s, e.g. in the Intelligenzblatt zur Laibacher Zeitung, no. 6, January 15, 1828, [24]: "Grätzer-Redout-Original-Deutsche für 1828, für Piano-Forte, von Grafen Christoph Bathyani”; further Intelligenzblatt zur Laibacher Zeitung, no. 16, February 7, 1828, 66; ibid., no. 7, January 15, 1829, 28; ibid., no. 21, February 18, 1830, 82.

95 The NUK, Music Collection holds prints of Hysel's Deutsche Tenze en potpourri from Franz Ferstl's publishing house, performed at the ceremonial installation of the Regional Governor Ignaz Count von Attems on 17 January 1821 in Graz, and the first part of the Grätzer-Redout-Deutsche for the Carnival of 1823 (Ferstl). The composite manuscript in the NUK, Music Collection marked "W. A. Mozart, Walzer" also contains a transcription of Hysel's Deutsche aus der SchweitzerFamilie, i.e. dances to motifs from Joseph Weigl's Singspiel. Also Maschek offered transcriptions of Hysel's Deutsche in his advertisement in the Intelligenzblatt zur Laibacher Zeitung, no. 7, January 22, 1822, 102 (see Appendix 2, no. 16).

96 Schuller served as a military chaplain. In 1828 he became an honorary member of the Musical Association for Styria. See Susanne Flesch, "Die Ehrenmitglieder des Musikvereins für Steiermark," in Im Jahrestakt: 200 Jahre Musikverein für Steiermark, eds. Michael Nemeth and Susanne Flesch (Wien, Köln, and Weimar: Böhlau Verlag, 2015), 250. 
Schuller's 1821 volume ${ }^{97}$ and two manuscript volumes ${ }^{98}$ have been preserved in Ljubljana to this day. Schuller contributed a set of six Deutsche specifically for the Laibacher Redoutesaal in $1825^{99}$ and, on the other hand, Baron Lazarini, well known in Ljubljana, intended at least one set of dances for performances in Graz. ${ }^{100}$ The cultural links between Graz and Ljubljana were indeed numerous.

\section{The Distinctive Sound and Music of the Laibacher Deutsche}

The Laibacher Deutsche are preserved exclusively in piano scores and not in versions for other ensembles mentioned in the advertisements. The orchestral voices existed only in manuscripts and were soon lost, as the dance music was topical and in use for only a short period of time. Year after year, the music market demanded the production of new compositions.

It is possible to get closer to the original sound by means of the instrumental markings, which are written in certain places in some of the piano scores, such as "mit 2 Klappentromp." in the trio of the fifth Deutscher, or "mit 4 Tromp." in the sixth Deutscher, where Lazarini accentuated the final dance of his 1827 Schießstatt-Deutsche by a four-part chordal sound of booming natural trumpets. ${ }^{101}$ Natural trumpets were rarely used as solo instruments due to the limitations of their tonal range. ${ }^{102}$ The fashionable keyed trumpet ${ }^{103}$ offered the possibility of performing melodies with chromatic tones, as exemplified in the above-mentioned Lazarini's fifth trio in the chromatically descending tones of the melody $\mathrm{D}-\mathrm{C} \#-\mathrm{B} \#-\mathrm{B}-\mathrm{A}$ and its third doubling $(\mathrm{F} \#-\mathrm{E}-\mathrm{D} \#-\mathrm{D}-\mathrm{C} \#)$. The sound of the keyed trumpet was reminiscent of the oboe or clarinet, and critics often disliked the instrument. Felix Mendelssohn even described its sound as "like a trumpet castrato, so dull and unnatural." 104 The instrument was also used solo by Ledenig in the 1827 season in his third trio and fourth Deutscher (VI Laibacher Redout Deutsche samt Trios), and after the solo opening, after

97 Redout Deutsche aus weiter Ferne für den Carneval des Jahres 1821: Als Zeichen herzlicher Erinnerung an die Bewohner von Grätz Ibrem Vergnügen erfurchtsvoll gewidmet von Schuller fürs Piano-Forte; Grätz: In Kommission bey Franz Ferstl, NUK, Music Collection.

98 Gretzer Redoutt Deutsche für den Carneval 1817 für das Piano-Forte von Scbüller and the already mentioned Redoutt Deutsche für's Piano Forte von Martin Schuller [n. d.], NUK, Music Collection.

99 See Appendix 2, no. 32.

100 VI Allemandes avec Trios de l'annáe [sic] 1819 du noble Casino de Gratz pour le Piano-Forte composées et dediées A Madame le Comtesse de Mazzuchelli née d'Eÿderÿ par Louis Baron de Lazarini: Partie I; Graz au Magazin de Musique chez Ferstl. A-Wn M.S.11271.

101 Lazarini, Sechs Laibacher Schiessstatt Deutsche mit Trios, 1827.

102 Beverly Jerold, The Complexities of Early Instrumentation: Winds and Brass, Musical Treatises 3 (Turnhout: Brepols, 2015), 104.

103 The keyed trumpet (Klappentrompete) is a late eighteenth-century invention that lasted only until around 1840, bridging the transition from the original natural trumpet to the modern valve trumpet. Its sound was softer and less penetrating. See Jerold, The Complexities of Early Instrumentation, 104.

104 Ibid., 105. 
eight bars, he added the marking "Orchester". Like Lazarini, he concluded the sixth trio of his set with the marking "zwey Klappentromp." The trumpets were therefore not only typical of the Schießstatt-Deutsche, they were also in use in the Redoutensaal (see Appendix 1, nos. 4-5).

The given examples of Lazarini and Ledenig suggest that the representative Laibacher Deutsche, with brass and wind instruments, sounded louder and quite different from the later waltzes of Lanner or Strauss, where the strings took the lead in the orchestral sound. It seems that the Laibacher Deutsche have preserved the original sound of this music and dance form from the time of its heyday in Vienna. Johann Pezzl, in his literary sketch of Vienna (1787), described the carnival madness in the ballrooms in his description of the imperial Redoutensäle and mentioned the characteristic contrasting sound of dance music: "[...] one's ears are enchanted and captivated by fanfares of trumpets and drums, intermingled with the softer tone of a hundred musical instruments." 105 The larger halls in Vienna also had several orchestras per dance evening, and it would be interesting to know whether the organisers of public dances in Ljubljana could afford a similar luxury.

In the sets of Deutsche for the 1828 and 1830 seasons, Ledenig also mentions the trombone and the post horn (Posthorn), besides the keyed trumpet, whereas in Johann Carl Fischer's 1828 account the record of "Clar. in F" (clarinet in $\mathrm{F}$ or alto clarinet) appears. References to instruments in piano scores can also be found in Micheuz, who mentions a post horn in his undated set of Deutscher, and three trumpets and a horn in 1827. The question of whether the dance music of the Laibacher Deutsche might have been performed by military brass bands consisting of wind, brass and percussion instruments remains unanswered for the time being, but the markings of the instruments suggest that it was indeed the Militärkapellen that performed the music at the dances. ${ }^{106} \mathrm{In}$ this context, it is also interesting to note that in Ljubljana in 1826-1828, at the newly founded Philharmonic Society's music school there was much more interest in the lessons of wind instruments than in those of strings. ${ }^{107}$

In terms of form, the surviving Laibacher Deutsche consist of a set of six Deutsche with trios, with the exception of one, which contains seven. ${ }^{108}$ The Laibacher Deutsche occasionally have an eight-bar introduction at the beginning,

105 "[...] Timpani and trumpet sounds, blended with the softer tones of a hundred musical tools, stir the delighted ear."Johann Pezzl, Skizze von Wien (Wien and Leipzig: Krausische Buchhandlung, 1787), 4: 515. Quoted in Eric McKee, Decorum of the Minuet, Delirium of the Waltz: A Study of Dance-Music Relation in 3/4 Time (Bloomington: Indiana University Press, 2012), 85-86.

106 Cvetko, Zgodovina glasbene umetnosti, 15.

107 The wind section, headed by Johann Wagner, enrolled 27 students, while the string section, headed by Josef Beneš, had 16. Cvetko, Zgodovina glasbene umetnosti, 134-135.

108 Fischer, Laibacher Redout-Deutsche, 1829. 
marked Eingang, ${ }^{109}$ Introduction $^{110}$ or Entrata ${ }^{111}$ (see Appendix 1, no. 1). In only one case does the set end with a coda. ${ }^{112}$ Without a special marking, the Deutsche sets by Micheuz ${ }^{113}$ and Fluck begin with a shorter four-bar introduction. This serves as preparation for the dance, and arouses anticipation in the dancers. The independent introduction, quite often mentioned in foreign music prints of Deutsche, is not to be found in the Ljubljana sets. On the contrary, the coda as the conclusion of the set and a clear sign to the dancers that the dance is coming to an end is mentioned, at least in the advertisements of the Laibacher Deutsche sets, more often than it is actually represented in the extant examples.

The Deutscher is characterised by diversity (see Appendix 1). Its melodic, rhythmic and formal structure is anything but uniform. ${ }^{114}$ While this fact complicates the analysis, it is its musical content rather than its form that determines the recognisability of the (Laibacher) Deutscher. Unlike the Ländler or the waltz, whose musical course is uniform and flows steadily from beginning to end, in the Deutscher it is constantly changing and shifting. The non-uniformity is obviously a reflection of the choreographic flow, which constantly encourages dancers to alternate between the two natural principles of tension and relaxation. This duality, in its physical realisation of the Deutscher in the nineteenth century, was composed of two permanent choreographic figures: the spinning of the couples in a closed posture and the promenade of the couples in an open posture. ${ }^{115}$ The Deutscher's musical mood therefore fluctuates and transitions from one state to the other. The impermanence perhaps a remnant of the Sturm und Drang movement of the late eighteenth century - is in fact its most distinctive characteristic.

The Deutscher can be described as a highly performative musical genre. The choreographic form is not standardised and varies from case to case and obviously also depends on the external circumstances of the specific performance (size of the hall, number of dancing couples, etc.). It is crucial that any changes in the choreographic flow be acoustically clearly identifiable, ${ }^{116}$ which often leads to excessive explicitness. For example, calm melodies are often stopped

109 Micheuz, Sechs neue brillante Original Laibacher-Schiessstatt-Deutsche, 1826; Micheuz, Original Laibacher Schiessstatt Deutsche, 1. Abteilung, 1827.

110 Lazarini, Sechs Laibacher Schiessstatt Deutsche, 1827.

111 Ledenig, VI Laibacher Redout Deutsche, 1827.

112 Micheuz, Sechs neue brillante Original Laibacher-Schiessstatt-Deutsche, 1826.

113 Micheuz, Original Laibacher Schiessstatt Deutsche, 1827.

114 Walter Deutsch, "Der 'Deutsche'," in Tanzmelodien aus München um 1800: 61 Deutsche und Ländler in einer Handschrift der Bayerischen Staatsbibliothek, eds. Bezirk Oberbayern and Die Landeshauptstadt München (München: Bezirk Oberbayern, 1999), 43.

115 Whether the promenade in the Laibacher Deutscher remains free in terms of space or coordinated with the leading dance couple around the circle of the hall remains an unsolved riddle.

116 Given this variety and the non-standardised choreographic form, it seems highly likely that dancers performed the Deutscher under the guidance of a lead dancer (Vortänzer). 
by a sforzando, chromatic melodic progressions, or diminished chords before their conclusion. The waltz's recognisable "oom-pah-pah" accompaniment suddenly stops and resumes with full chords, modifyng the flow. At times, the sonic fullness of the chords is also brusquely interrupted by one-note octave progressions, as if the boisterous sound and choreographic spinning needs to be quelled (see Appendix 1, no. 3). The Deutscher's music-dance dramaturgy is based on contrast, which also emerges from the music, with its constant alternation of piano-forte dynamics. The gentler melodies in the trio (often marked dolce, con amore, con sentimento, or leg $[\mathrm{g}]$ ermente) are interrupted by the more boisterous passages indicated by the tutta forza marking. ${ }^{117}$ The sudden change of structure very often appears right at the beginning of the trio's second part (see Appendix 1, nos. 3, 6-9).

The melody and rhythm of the Deutscher often use stylised Ländlertype and old-waltzlike melodic elements. Ländler-like melodies are easily recognisable by the fragmented rhythmic progression of the quavers, which mostly have a characteristic harmonic sequence in the first part of the eightbar period (T-T-D-T/T-T-D-T) as well as in the following part (D-T-DT/T-T-D-T) (see Appendix 1, nos. 7-8). Waltzlike melodies are recognisable by the characteristic initial rhythm of the minim with a crotchet (see Appendix 1, nos. 10-11). Walter Deutsch describes the variety of melodic structures in the Deutscher, which can resemble Ländler, minuet or waltz, as the most characteristic moment of this dance: "The 'reminiscences' of the Ländler, minuet and waltz were probably the link that supported the diversity of the Deutscher, a diversity in which ever new expressions of firmly established musical ideas are being realised." 118 Deutsch points out, however, that the similarities in melodic structures and formal elements cannot be considered a typological correspondence or any evidence of evolutionary processes in which one dance form developed from another, but rather a reflection of the general musical style at the time of their appearance: "Occasional occurrences of similarities in melodic shape and form between minuet, Deutscher, Ländler and waltz can only be explained by the style of the time and cannot be interpreted as typological agreement." 119

The fanfare introductions, which occasionally appear in the transitions, give the music and dance form an air of grandeur, gravitas and sometimes pomposity, and in their musical content they refer to the tradition of the minuet. Mozart's

117 Lazarini, VI Laibacher Redout Deutsche, 1830.

118 'Die 'Reminiszenzen' an Ländler, Menuett und Walzer waren wohl das Bindeglied, das die Mannigfaltigkeit des Deutschen stützte, eine Mannigfaltigkeit, in der immer wieder neue Ausprägungen festgefügter musikalischer Ideen verwirklicht werden.” Deutsch, “Der 'Deutsche', 25.

119 "Fallweises Auftreten von Ähnlichkeiten in Melodiegestalt und Formverlauf zwischen Menuett, Deutschem, Ländler und Walzer kann nur aus dem Zeitstil erklärt werden und nicht als typologische Übereinstimmung gedeutet werden." Deutsch, “Der 'Deutsche'," 23. 
experience of writing dance music for the Viennese Großer Redoutensaal had already led him to realise that in a large hall with a crowd of people, the minuets and Deutsche had to be louder ${ }^{120}$ and, above all, had to signal the beginning of the dance with a more percussive and resounding introduction. In the trio of the minuet and later the Deutscher, a more elegant dance character comes to the fore, as the Deutscher has adopted from the minuet practically all the elements that have proved useful and effective in ballroom dance practice.

The upbeat cannot be described as a hallmark of the Deutscher, but all Laibacher Deutsche begin with it. It varies according to the basic character and melodic structure of the given phrase. An upbeat may consist of a crotchet, two quavers, three quavers, or a quaver triplet.

From the surviving examples of the Laibacher Deutsche, it is clear that the entire set was performed as a series at dance events. The tonalities of the individual dances in the set are often carefully chosen for tonal affinity, often in the order of the circle of fifths. Even throughout the set, there is a deliberate dramaturgy in the flow, as the basic character of the individual dances changes and develops, from the usually chordally accentuated and boisterous first and last dances, to the slightly more lyrical intermediate movements, with the emphasis on a more tuneful melody or, for example, a Ländler-like harmony with prevailing broken chord melodic passages.

It is not possible to discern from the surviving music the number of repetitions of individual dances. The composers probably left this decision to the performers and the circumstances of the moment. That there were several repetitions of one dance before the beginning of the next is suggested, for example, by Ledenig in his Redout-Deutscher of 1830. At the end of the first trio he wrote: "Each repetition of the first Deutscher starts from the Entrata." ${ }^{21}$

From today's perspective and the aural familiarity of the minuets often performed in modern times, it seems self-evident that the first part should be repeated after the trio and that the Deutsche, like the minuets, were performed in the sequence $\mathrm{A}-\mathrm{B}-\mathrm{A}$. Was this also a given for nineteenth-century musicians, dancers and listeners? Except in the case of Micheuz's Schießstatt-Deutsche

120 Johann Pezzl says that while the Redoutensäle in Vienna were better attended when they were founded, in recent years people prefer private dance events and picnics. Nevertheless, the Redouten are still quite glamorous, especially in the last weeks of the carnival season: "Wenn nur tausend Personen da sind, ist es zu einsam. Anderthalbtausend Köpfe machen eine bequeme Redute, in diesem Fall ist eben noch Raum genug zum tanzen. Zweitausend verstellen den Tänzern schon den nöthigen Plaz [sic]. In den letzten Tagen, wenn sich die Freudenjäger bis gegen dreitausend einfinden, dann ist man in der Presse." Pezzl, Skizze von Wien, 516. "If only a thousand people attend, it feels too lonely; 1,500 dancers make a nice Redout, and with that number there is still enough room to dance. With 2,000 there in no longer room to dance properly, and in the last few days, when there may be up to 3,000 pleasure seekers, it is a real squeeze.") Quoted in McKee, Decorum of the Minuet, 85-86.

121 “Bey jeder Wiederholung des $1^{\text {ten }}$ Deutschen wird von der Entrata angefangen." Ledenig, VI Laibacher Redout Deutsche (1827), 1. 
of 1825 , where the end of every Deutscher was marked with fine and da capo (A-B-A) came at the end of each trio, this kind of sequence is not really apparent in the notated music. In fact, the trio often has a different tonality to the Deutscher, most often the two parts are in a dominant relationship, but the trio is often also in a tonal relationship with following Deutscher and the transition to the next dance also makes sense. In Lazarini's Redout-Deutscher of 1830, the fine marking can only be found at the end of the last trio, and Bosizio's Deutscher of 1831 even has these markings in the central part of the trio.

Mozart's handwritten note in the autograph of his German Dances KV 509 of 1787 may help clarify the standard sequence of repeats in the Deutscher. On the reverse, Mozart wrote that each Deutscher had its own trio or - as he called it - Alternativo. After the Alternativo, he repeats the Deutscher and then plays the Alternativo again before the next Deutscher follows. ${ }^{122}$ The standard form of the Deutscher would then be A-B-A-B. This is certainly feasible and plausible for most of the Laibacher Deutscher, but it seems that a different sequence of repetitions is also possible. Even within a single set, the dances often differ from each other in the length of the periods, the placement of the repeat signs and the places marked da capo and fine.

Is the number of bars or the length of a piece at all indicative of the choreographic flow? It seems that the choreographic segmentation in the Deutscher does not coincide with that of the music, just as, for example, in the minuet, the six-bar choreographic Z- or S-figure does not correspond to the eight-bar periods in the music. However, the analysis of the music with its contrasting parts shows that the spinning of the Deutscher was probably performed at short but frequent intervals.

To summarise, the music of the Laibacher Deutscher shows a remarkable variety of musical ideas and compositional practices. The music may seem simple at first sight, yet its most important quality is precisely the functionality, which had to prove its usefulness on the ballroom floor.

\section{Conclusions}

In the second half of the nineteenth century, Slovenia witnessed a remarkable rise of national ideas, which in the twentieth century escalated into an extreme aversion to anything that might resemble the once flourishing German culture. These ideas led to the rejection of the German Dance of the 1820s, which quickly faded into oblivion. To this day, the Laibacher Deutscher has not

122 "Jeder teutsche hat sein Trio, oder vielmehr Alternativo; - nach dem Alternativo wird der teutsche wieder wiederhollet, dann wieder das Alternativo; dann geht es durch den Eingang weiter in den folgenden teutschen." By Eingang, Mozart probably means Übergang, as he linked the dances together by transitions. Wolfgang Amadeus Mozart, Neue Ausgabe sämtlicher Werke, Serie IV: Orchesterwerke, Werkgruppe 13: Tänze und Märsche, vol. 2, ed. Marius Flothius (Kassel, Basel, and London: Bärenreiter, 1988), 24. 
attracted much interest among researchers of the musical past, although, for various reasons, it proves to be an extremely interesting phenomenon when studied in more detail.

The dance form of the bourgeois Deutscher took shape and reached its peak of popularity at the end of the eighteenth century in Vienna. At the beginning of the nineteenth century, as the waltz became increasingly vogue in the imperial capital and interest in it waned, the Deutscher's popularity in other parts of the Habsburg lands, most notably in Graz, grew. Ljubljana could not have adopted this dance fashion from Vienna, but was probably inspired by the Styrian capital. The Deutscher came to life in Ljubljana at the latest in the spring of 1821, immediately after the Congress of Laibach. The Laibacher Deutscher is a late phenomenon in the wider context, and Ljubljana was probably one of the last cities where this dance flourished.

The Laibacher Deutscher can be characterised as a cultural product of a specific diplomatic event, the Congress of Laibach - it is certainly evident that it represents a direct socio-cultural response to the political situation of that time. The Deutscher, the most fashionable dance of the 1820s in Ljubljana, also served ideological purposes in the decade following the Congress, thus reinforcing the allegiance to German culture and the old political order.

The name Laibacher Deutscher in the 1820s also sounded like a trademark to promote the city and the composers active there. This dance further reflects the vibrant cultural and social pulse of the city and also the increasingly diverse music market. The new compositions offered each year by various composers did not only serve as dance music for public dance events, but their use was in fact much more varied. For example, they were performed for entertainment during intermissions of comedies staged in the theatre, and amateur musicians played them in their own homes on the piano or in small chamber ensembles for amusement and entertainment. No doubt, there was often dancing to this music in private homes.

The production of Deutscher music is also an interesting phenomenon from a social point of view, since at first sight it seems simple, functional music, where no in-depth knowledge of the musical phrase is required. At the same time, the form has clear regularities and character, the knowledge and mastery of which is essential for composition. Deutsche were not only composed by professional musicians, but also, and above all, by many amateurs from the bourgeoisie and the lower nobility.

Although there are no descriptions of the choreographic structure of the Laibacher Deutscher, a study of the wider context and, above all, an analysis of the music clearly shows that this dance form was by no means identical to the waltz. However, the waltz, which became increasingly popular over time, certainly played a decisive role in the decline of the Deutscher and also erased its traces in Ljubljana. 
A large number of sets of Deutsche, created in Ljubljana in the 1820s, are known today only from the advertisements of music publishers in the newspapers of the time. This genre of functional music, originally intended for one carnival season at most, has often been lost over time. Finally, the paper aims to draw attention to the array of preserved manuscripts and printed dance music, today part of the rich collection of this period, held in the Music Collection of the National and University Library in Ljubljana, but so far poorly researched by scholars and barely acknowledged by the general public.

\section{Translated by Marjana Benčina}

\section{Abbreviations}

A-Wgm: Gesellschaft der Musikfreunde in Wien, Archiv A-Wn: Österreichische Nationalbibliothek, Musiksammlung

A-Wst: Wienbibliothek im Rathaus, Musiksammlung

GZ (SIB): Steyermärkische Intelligenzblätter zur Grätzer Zeitung

GZ: Grätzer Zeitung

LZ (AB): Amtsblatt zur Laibacher Zeitung

LZ (Anh.): Anhang zur Laibacher Zeitung

LZ (IB): Intelligenz-Blatt zur Laibacher Zeitung

LZ: Laibacher Zeitung

NMS: Narodni muzej Slovenije / National Museum of Slovenia

NUK: Narodna in univerzitetna knjižnica, Glasbena zbirka / National and University Library, Music Collection (SI-Lng)

WZ: Wiener Zeitung

\section{Sources and Bibliography}

Brocza, Pia, and Marko Motnik. "Georg Link und seine Tanzschule von 1796." De musica disserenda 10, no. 2 (2014): 33-55. https://doi.org/10.3986/ dmd10.2.03.

Brunner, Verena. Contredanses: Tanzvergnügen der Mozart-Zeit; Kontratänze, Tanzbeschreibungen, Historisches. Boppart am Rhein: Fidula-Verlag, 2014.

Budna Kodrič, Nataša. Korespondenca Jožefine in Fidelija Terpinc (1825-1858). Objava arhivskih virov 41. Ljubljana: Arhivsko društvo Slovenije, 2018.

Cigoj Krstulović, Nataša. "Med sentimentom in razumom: K zgodovini in pomenu valčka za klavir v 19. stoletju na Slovenskem.” Muzikološki zbornik 46, no. 2 (2010): 37-56. https://doi.org/10.4312/mz.46.2.37-56.

Cigoj Krstulović, Nataša. "Posvetila na skladbah kot izhodišče za razpoznavanje kulturne zgodovine 19. stoletja na Slovenskem.” Kronika 56, no. 3 (2008): 473-494.

Cvetko, Dragotin. Zgodovina glasbene umetnosti na Slovenskem. Vol.2. Ljubljana: Državna založba Slovenije, 1959. 
Daul von Fürstenberg, Florian. Tantzteuffel: Das ist / wider den leichtfertigen / onuerschempten Welt tantz / ond sonderlich wider die Gott及 zucht ond ehrvergessene Nachttäntze. Facsimile, edited by Kurt Petermann. Documenta choreologica 8. München: Heimeran, 1978.

Deutsch, Walter. “Der 'Deutsche'.” In Tanzmelodien aus München um 1800: 61 Deutsche und Ländler in einer Handschrift der Bayerischen Staatsbibliothek, edited by Bezirk Oberbayern and Die Landeshauptstadt München, 22-46. München: Bezirk Oberbayern, 1999.

Feldtenstein, C[arl] J[oseph] von. Erweiterung der Kunst nach der Chorographie zu tanzen, Tänze zu erfinden, und aufzusetzen; wie auch Anweisung zu verschiedenen National-Tänzen; Als zu Englischen, Deutschen, Schwäbischen, Pohlnischen, Hannak-Masur-Kosak- und Hungarischen; mit Kupfern; nebst einer Anzabl Englischer Tänze. Braunschweig: [s. n.], 1772.

Flesch, Susanne. "Die Ehrenmitglieder des Musikvereins für Steiermark." In Im Jahrestakt: 200 Jahre Musikverein für Steiermark, edited by Michael Nemeth and Susanne Flesch, 223-260. Wien, Köln, and Weimar: Böhlau Verlag, 2015.

Friedel, Johann. Galanterien Wiens, auf einer Reise gesammelt, und in Briefen geschildert von einem Berliner. Vol. 1. [Wien]: [s. n.], 1784.

Goethe, Johann Wolfgang von. Die Leiden des jungen Werthers. Leipzig: Weygandsche Buchhandlung, 1774.

Gothaisches genealogisches Taschenbuch der Freiherrlichen Häuser. Vol. 69. Gotha: Justus Perthes, 1911.

Green, Emily H. Dedicating Music, 1785-1850. Rochester: University of Rochester Press, 2019.

Holz, Eva. Ljubljanski kongres 1821. Ljubljana: Nova revija, 1997.

Jerold, Beverly. The Complexities of Early Instrumentation: Winds and Brass. Musical Treatises 3. Turnhout: Brepols, 2015.

Krstulović, Zoran. "Značilnosti kompozicijskega stavka L. F. Schwerdta s posebnim ozirom na njegove maše.”Masterthesis, Univerza v Ljubljani, 1998.

Kuret, Primož. "Kongresno leto 1821 in Gašpar Mašek." In Maškov zbornik, edited by Edo Škulj, 27-39. Ljubljana: Družina, 2002.

Länger, Christian. Terpsichore: Ein Taschenbuch der neuesten gesellschaftlichen Tänze, worin zugleich Anweisung gegeben wird, wie man 40 Touren und 76 Tänze obne orchesigraphische Zeichnungen und ohne Lehrer erlernen kann; Zum Nutzen und Vergnügen für Freunde der Tanzkunst. Würzburg: Etlinger, 1824.

Litschauer, Walburga, and Walter Deutsch. "Deutscher Tanz." In MGG Online. Accessed June 30, 2021. https://www.mgg-online.com/mgg/stable/12484. McKee, Erich. Decorum of the Minuet, Delirium of the Waltz: A Study of DanceMusic Relation in 3/4 Time. Bloomington: Indiana University Press, 2012.

Metternich-Winneburg, Richard, and Alfons v. Klinkowström, eds. Aus Metternich's nachgelassenen Papieren: Friedens-Aera 1816-1848. Vol. 3. Wien: Wilhelm Braunmüller, 1882. 
Mozart, Wolfgang Amadeus. Neue Ausgabe sämtlicher Werke. Serie IV: Orchesterwerke, Werkgruppe 13: Tänze und Märsche. Vol. 2, edited by Marius Flothius. Kassel, Basel, and London: Bärenreiter, 1988.

Neuestes Sittengemäblde von Wien. Wien: Anton Pichler, 1801.

Nicolai, Friedrich. Beschreibung einer Reise durch Deutschland und die Schweiz, im Jahre 1781. Nebst Bemerkungen über Gelehrsamkeit, Industrie, Religion und Sitten, vol. 3. Berlin and Stettin: [s. n.], 1784.

Noverre, Jean Georges. Lettres sur la Danse, et sur les Ballets, par M. Noverre, Maître des Ballets de Son Altesse Sérénissime Monseigneur le Duc de Wurtemberg, Eo ci-devant des Théatres de Paris, Lyon, Marseille, Londres. Lyon: Aimé Delaroche, 1760.

Petersen, Peter. "Nochmals zum Tanz-Quodlibet im ersten Akt-Finale des Don Giovanni." Archiv für Musikwissenschaft 65, no. 1 (2008): 1-30.

Pezzl, Johann. Skizze von Wien. Wien and Leipzig: Krausische Buchhandlung, 1787.

Podlesnik Tomášikova, Lidija. "Plesni mojstri Kranjskih deželnih stanov v 18. in 19. stoletju." Muzikološki zbornik 47, no. 1 (2011): 113-140. https://doi. org/10.4312/mz.47.1.113-140.

Popowitsch, Johann Siegmund Valentin. Vocabula Austriaca et Stiriaca. Vol. 2, edited by Richard Reutner. Schriften zur deutschen Sprache in Österreich 23. Frankfurt am Main: Peter Lang, 2004.

Preinfalk, Miha. "Genealoška podoba rodbine Zois." Kronika 51, no. 1 (2003): 27-50.

Radics, Peter von. Geschichte der Rohrschützen-Gesellschaft des k. k. priv. LandesHauptschießstandes Laibach unter dem hohen Protectorate Sr. k. k. Hoheit des durchlauchtigsten Herrn Erzherzogs Ernst: Festschrift zur 600jäbrigen Jubelfeier der Zugehörigkeit Krains zu Österreich. Laibach: Ig. V. Kleinmayr \& Fed. Bamberg, 1883.

Rahten, Andrej, Gregor Antoličič, and Oskar Mulej, eds. Ljubljanski kongres 1821: Diplomatska študija Vladimirja Šenka - znanstvenokritična izdaja. Studia diplomatica Slovenica, Monographiae 5. Celovec [Klagenfurt], Ljubljana, and Dunaj [Wien]: Mohorjeva založba, 2020.

Rimmer, Joan. "Allemande, Balletto and Tanz." Music \& Letters 70, no. 2 (1989): 226-232. https://doi.org/10.1093/ml/70.2.226.

Schematismus von Krain und Kärnten vom Jahre 1826. Laibach: Leopold Eger, [1826].

Schenk, Erik. "Der Langaus." Studia Musicologica Academiae Scientiarum Hungaricae 3, no. 1 (1962): 301-316.

Schollmayr-Costa, Cornelia. "Alte Tagebücher I." Laibacher Zeitung, no. 121, May 28, 1892: 1032-1036.

Schönherr, Max, and Karl Reinöhl. Johann Strauss Vater: Ein Werkverzeichnis. London, Wien, and Zürich: Universal Edition, 1954. 
Sivec, Jože. "Rossinijeve opere na odru Stanovskega gledališča v Ljubljani." Muzikološki zbornik 1 (1965): 37-49.

Sivec, Jože. Opera na ljubljanskih odrih od klasicizma do 20. stoletja: Izbrana poglavja, edited by Metoda Kokole and Klemen Grabnar. Ljubljana: Založba ZRC, ZRC SAZU, 2010.

Šmid, Walter. "Aus Alt Laibach." Carniola: Mitteilungen des Musealvereins für Krain 2, nos. 3-4 (1909): 143-153.

Specht, Bernard. Ueber Anstand, Schönheit und Grazie im Tanz: Nebst einem Vorschlage zur allgemeinen Balltracht. Prag: [s. n.], 1789.

Suhadolnik, Jože. Stari trg, Gornji trg in Levstikov trg: Arhitekturni in zgodovinski oris mestnih predelov in objektov, lastniki his ter arbivsko gradivo Zgodovinskega arbiva Ljubljana. Ljubljana: Zgodovinski arhiv, 2003.

Thomas, Günter. "Studien zu Haydns Tanzmusik." Haydn-Studien 3, no. 1 (1963): 5-16.

“Tomaževec, Simon (1805-?).” Slovenska biografija. Slovenska akademija znanosti in umetnosti, Znanstvenoraziskovalni center SAZU, 2013. Accessed July 10, 2021. http://www.slovenska-biografija.si/oseba/ sbi704239/\#slovenski-biografski-leksikon.

Tuschner, Wolfram. "Von den Linzer Tänzen zum Wiener Walzer: Landler Deutsche - Harbe Tanz.” Oberösterreichische Heimatblätter 46, no. 2 (1992): 209-239.

Weinmann, Alexander. Verlagsverzeichnis Giovanni Cappi bis A. O. Witzendorf. Beiträge zur Geschichte des Alt-Wiener Musikverlages 2, vol. 11. Wien: Universal Edition, 1967.

Weinmann, Alexander. Vollständiges Verlagsverzeichnis Artaria Eo Comp. Beiträge zur Geschichte des Alt-Wiener Musikverlages 2, vol. 2. Wien: Musikverlag Ludwig Krenn, 1985.

Witzmann, Reingard. "Der sogenannte 'Deutsche Tanz': Ein Beitrag zur Erforschung der Choreographie des Ländlers." Jahrbuch des Österreichischen Volksliedwerkes 25 (1976): 100-108.

Witzmann, Reingard. "Magie der Drehung - Zum Phänomen des Wiener Walzers von der Aufklärung zum Biedermeier." In Zur Frühgeschichte des Walzers, edited by Thomas Nußbaumer and Franz Grat1, 9-31. Schriften zur musikalischen Ethnologie 3. Innsbruck: Universitätsverlag Wagner, 2014.

Witzmann, Reingard. Der Ländler in Wien. Wien: Arbeitsstelle für den Volkskundeatlas in Österreich, 1976. 


\section{Appendix 1:}

Music examples featuring some characteristic elements of composition

1. An introduction with fanfare.

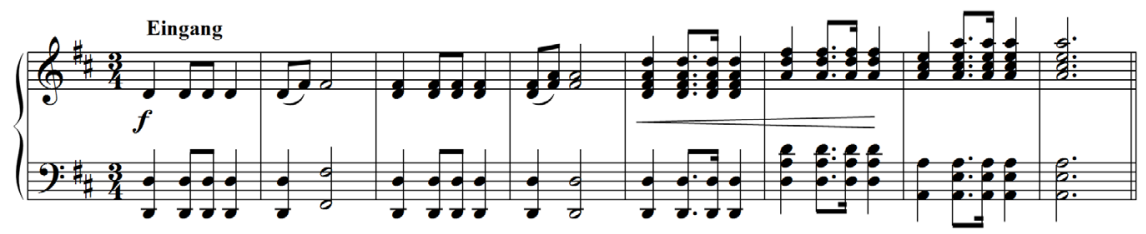

Georg Micheuz, Sechs neue brillante Original Laibacher-Schiessstatt-Deutsche (1826), "Eingang," bars 1-8.

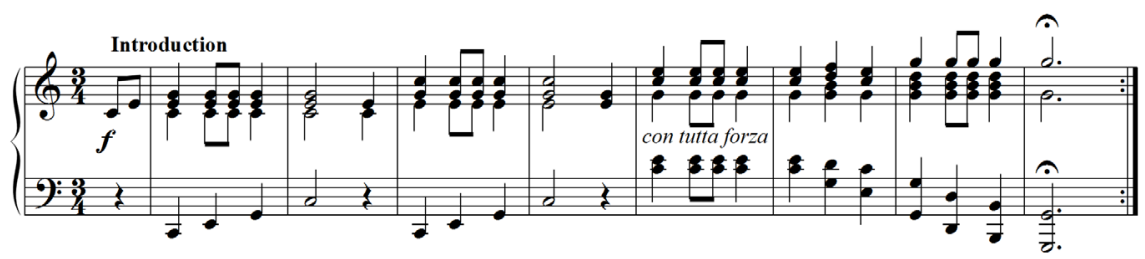

Louis von Lazarini, Sechs Laibacher Schiessstatt Deutsche (1827), "Introduction," bars 1-8.

2. A chord progression with fanfare in a typical dotted rhythm and with contrasting forte-piano dynamics between the Deutscher and the Trio.

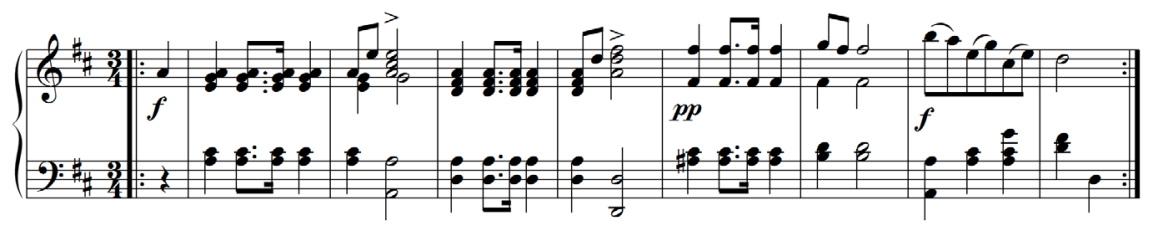

Georg Micheuz, Sechs neue brillante Original Laibacher-Schiessstatt-Deutsche (1826), Deutscher no. 1, bars 17-24. 
3. A transition in double octaves interrupting the melody of the "waltz".
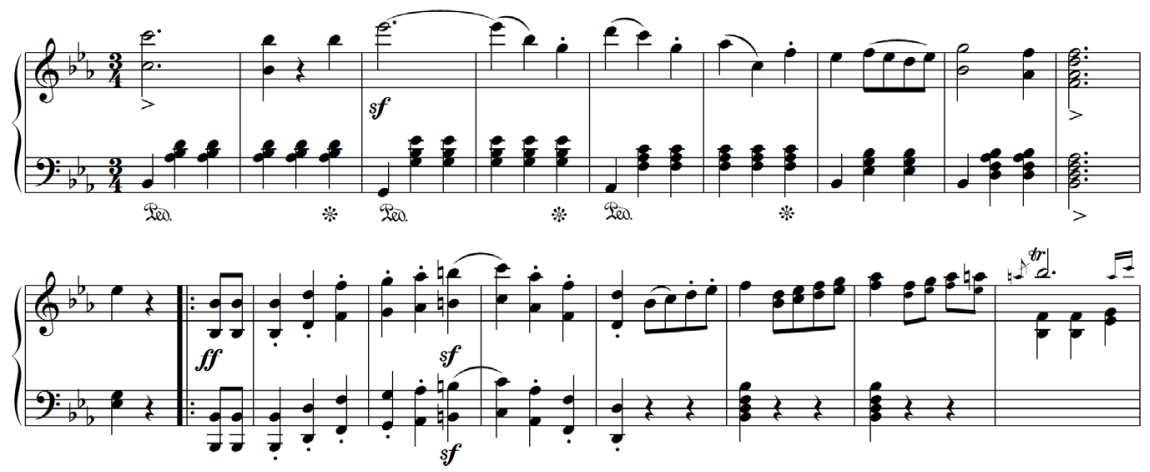

Leopold Cajetan Ledenig, Sechs Laibacher Redout Deutsche (1828), Trio no. 2, bars 7-23.

4. Chromatic descending steps in thirds played by two keyed trumpets.

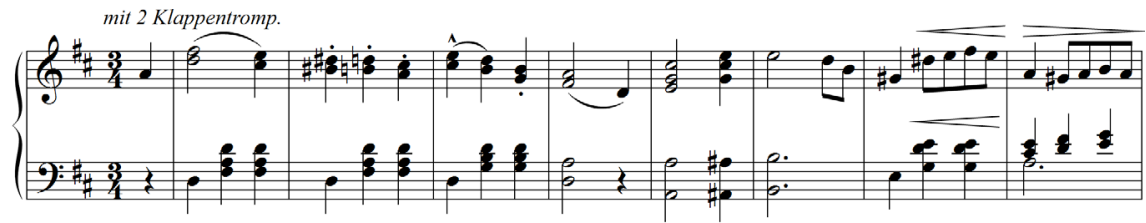

Louis von Lazarini, Sechs Laibacher Schiessstatt Deutsche (1827), Trio no. 5, bars 1-8.

5. A chord progression with trombone and a posthorn signal.

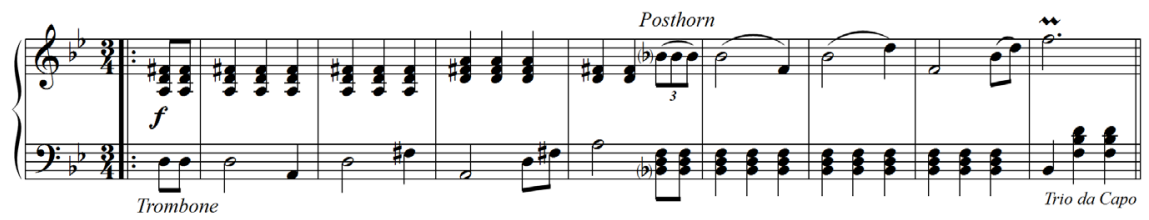

Leopold Cajetan Ledenig, Laibacher Redout-Deutsche (1830), Trio no. 4, bars 13-20. 
6. Sforzato on an unstressed beat.

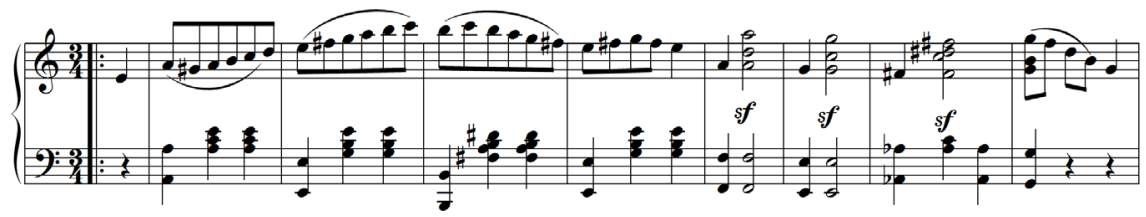

Johann Carl Fischer von Wildensee, Laibacher Redout-Deutsche (1829), Trio no. 6, bars 9-16.

7. A Ländler-like melody in fragmented rhythmic progression of quavers and a harmonic sequence $\mathrm{T}-\mathrm{T}-\mathrm{D}-\mathrm{T}$, with an inserted four-bar unison passage and chords in contrary motion in the soprano and bass lines.
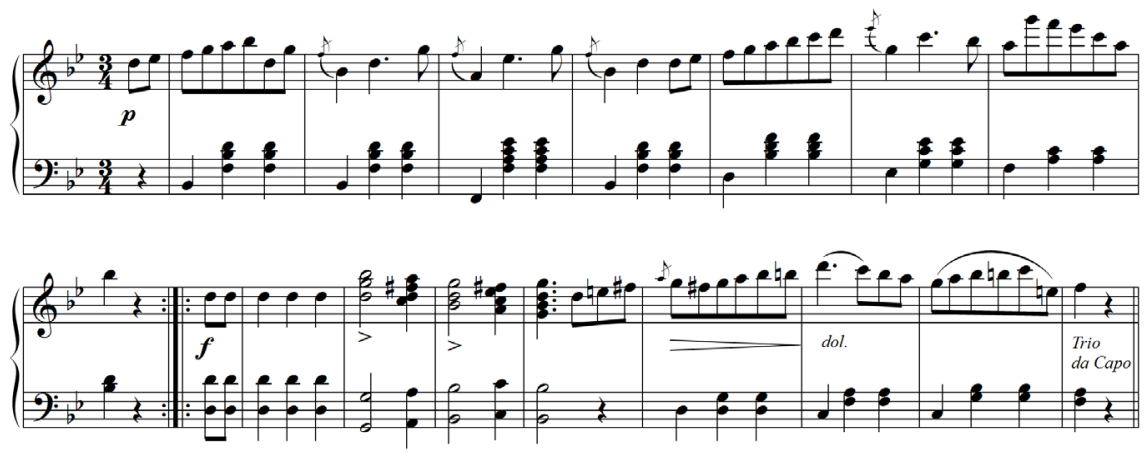

Franz Seraphin Nepozitek, Laibacher Redout Deutsche (1830), Trio no. 2, bars 1-16. 
8. A Ländler-like melody in fragmented rhythmic progression of quavers and a harmonic sequence of T-T-D-T-T (part 1, bars 1-8) and D-D-T-D-D (part 2, bars 13-16) with two inserted four-bar chord transitions and an accentuated bass line in octaves (bars 9-12 and bars 17-20).
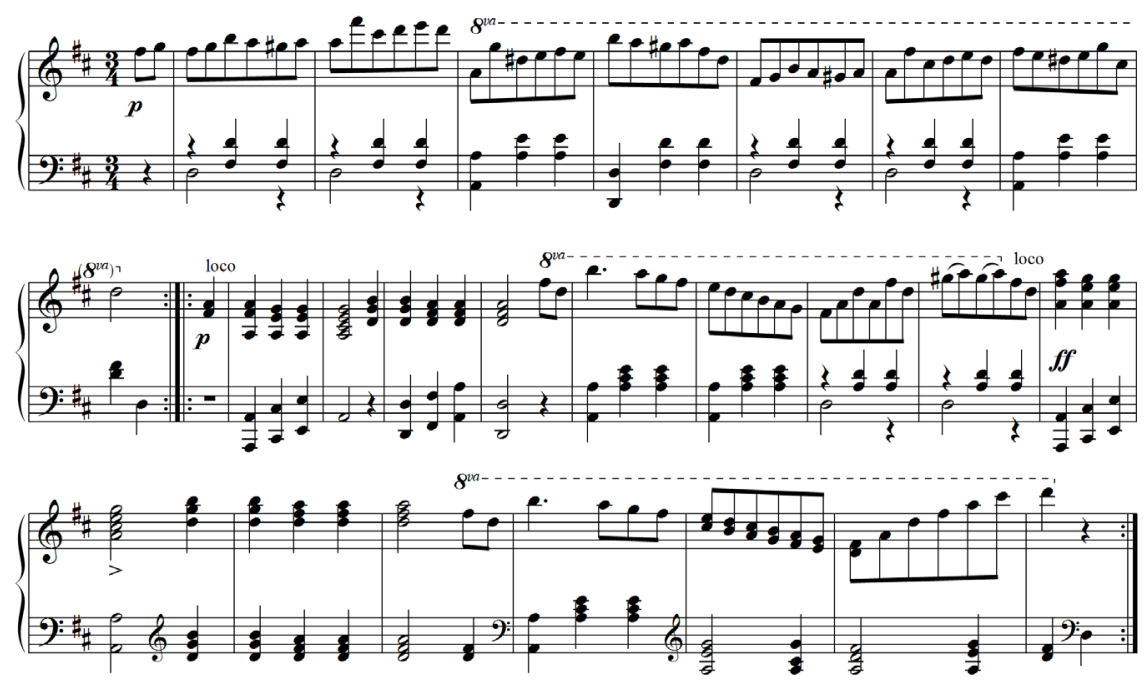

Georg Micheuz, Sechs neue brillante Original Laibacher-Schiessstatt-Deutsche (1826), Trio no. 1.

9. A Steirisch-like melody with a shift of rhythmic accent to the 4th quaver in bars 1 and 5 and a harmonic progression T-T-D-T.

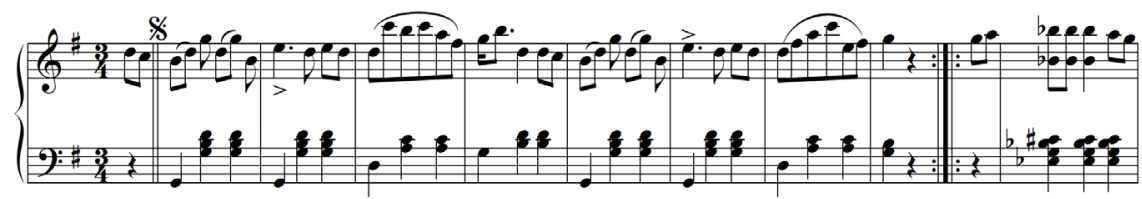

Franz Seraphin Nepozitek, Laibacher Redout Deutsche (1828), Trio no. 6, bars 1-10. 
10. A waltzlike melody with the characteristic rhythm of a minim and a crotchet and an "oom-pah-pah" accompaniment.

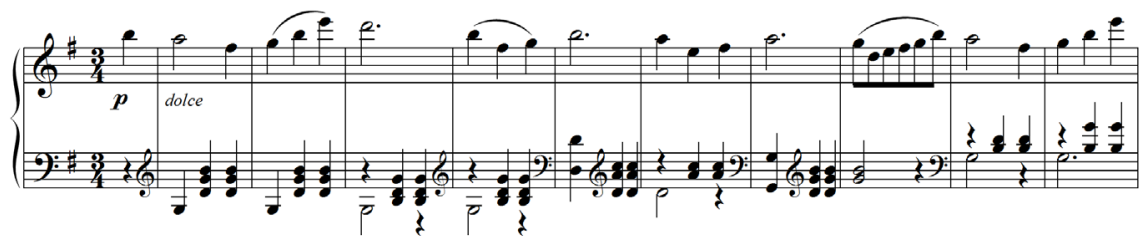

Georg Micheuz, Sechs neue brillante Original Laibacher-Schiessstatt-Deutsche (1826), Trio no. 2, bars 1-10.

11. A waltzlike melody with a variation of the basic rhythm of a dotted minim.

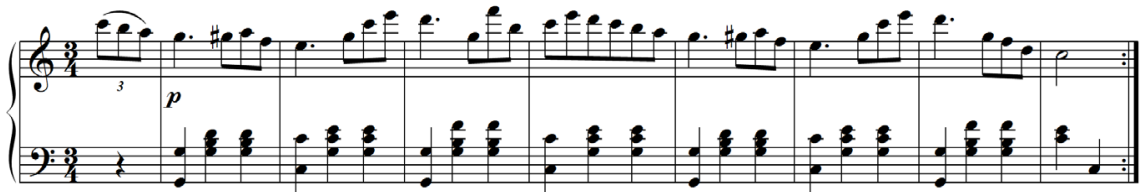

Georg Micheuz, Original Laibacher Schiessstatt Deutsche (1827), 2nd part, Deutscher no. 2, bars 1-8.

12. Perhaps a quotation of a "folk" song in thirds played in a lovely intermittent staccato.

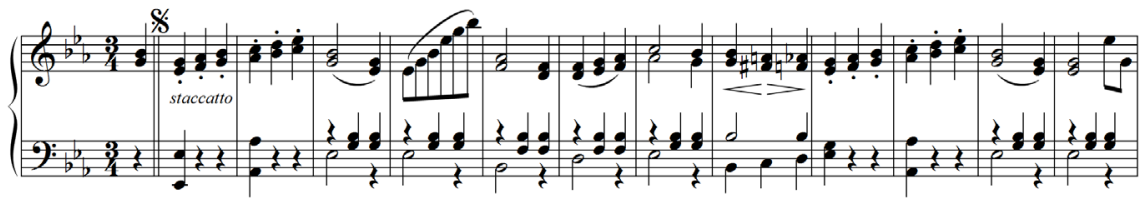

Georg Micheuz, Sechs neue brillante Original Laibacher-Schiessstatt-Deutsche (1826), Trio no. 3, bars 1-12. 


\section{Appendix 2:}

Advertisements and preserved copies of the Laibacher Deutsche (1815-1836)

\section{1815 [Author not named]}

Zwischen den Akten werden die diesjährigen Redout-Deutsche probirt.

Source: NMS, Comedien-Zettel Sammlung, 1814/15, 10 Jan 1815.

\section{1815 Leopold Ferdinand Schwerdt}

Zwischen den Akten werden neue deutsche Tänze componirt von Herrn Schwerd produzirt werden.

Source: NMS, Comedien-Zettel Sammlung, 1815/16, 31 Dec 1815.

Copy: Deutsche für das Piano Forte vom Schwerdt. NUK (Ms.).

\section{1817 Martin Schuller}

[...] künftigen Freytag als den 26ten Dezember wird, Johann von Calais gegeben, wobey wäbrend den Zwischenakten neue Deutsche, die während der Anwesenheit Sr. Maj. unsers allergnädigsten Monarchen in Grätz von Herrn Martin Schuller komponirt wurden, vorgetragen werden.

Source: NMS, Comedien-Zettel Sammlung, 1817/18, 21 Dec 1817; 26 Dec 1817.

Copy: Redoutt Deutsche fürs Piano-Forte von Martin Schuller. NUK (Ms.).

\section{1817 [Carl Handschuh?]}

Zwischen den Akten werden die von einem Herrn Dilletanten und dem Herrn Capellmeister des hiesigen löbl. k. k. Regiments componirten neuen RedouteDeutschen vorgetragen werden.

Source: NMS, Comedien-Zettel Sammlung, 1817/18, 28 Dec 1817.

Copy: Redoutt Deutsche fürs Piano-Forte von Carl Handschuh. NUK (Ms.).

\section{1818 [Author not named]}

In den Zwischenackten werden ganz neue Redout-Deutsche produzirt.

Source: NMS, Comedien-Zettel Sammlung, 1818/19, 21 Dec 1818.

\section{1819 [Author not named]}

In den Zwischenackten werden ganz neue Redout-Deutsche produzirt.

Source:: NMS, Comedien-Zettel Sammlung, 1818/19, 2 Jan 1819; 7 Jan 1819; 9 Jan 1819.

\section{1819 [Author not named]}

In den Zwischenakten werden ganz neue Redout-Deutsche, von der Composition eines hiesigen Musikfreundes produzirt werden.

Source: NMS, Comedien-Zettel Sammlung, 1819/20,18 Dec 1819. 


\section{1820 [Author not named]}

In den Zwischenackten werden ganz neue Redout-Deutsche produzirt.

Source: NMS, Comedien-Zettel Sammlung, 1819/20, 2 Jan 1820.

\section{9. c. 1820 Valentin Clementschitsch}

Copy: 6 Redout Deutsche Componirt und Gewidmed [sic] Der Hochgebohrnen Frau Gräfin von Auersperg gebohrenen Freyin von Wolkensperg von V. Clementschitsch. NUK (Ms.).

\subsection{0 [Author not named]}

Es sind im Stiche die in dem hiesigen Redouten-Saale produzirt werdenden neuen Deutschen mit Introd. und Coda, dann die 6 Original-Ländler für das Forte-Piano eigens gesetzt zu haben. Das Nähere ist täglich im sogenannten Schweitzer'schen Kaffehause zu erfragen. Die Deutschen kosten 48 kr. Die Ländler 30 kr.

Source: LZ (IB), 1 Feb 1820, 92; 4 Feb 1820, 117; 8 Feb 1820, 130.

\section{1.c. 1821-1824 Georg Micheuz}

Copy: Laibacher Deutsche für's Piano-Forte von Georg Micheuz. NUK (Ms.).

\subsection{Ferdinand Kauer}

Zwölf neue Laibacher Deutsche sind beym Unterzeichnetem im Manuscript zu haben. Erstens: Für ein volles Orchester á 10 f.W.W. Zweytens: Für Haußbälle, dreystimmig, 5 fl. Drittens: Für das Pianoforte zu 4 Hände 5 fl. Viertens: Für dasselbe zu 2 Hände 3 fl. Ferd. Kauer, Compositeur, wohnt in der Josephstadt Kaiserstrasse Nr. 103.

Source: WZ, 9 Feb 1821, 128; 12 Feb 1821, 136.

\subsection{Caspar Maschek}

In der deutschen Gasse Nr. 187, im 2. Stocke sind zu haben: Clavier-Auszüge aller Tänze, welche in der Carnevals-Zeit während des Congresses in Laibach im Jahre 1821 aufgeführt wurden, und zwar: 1. Deutsche Tänze sammt Trio's, nach Rossini's Barbier von Sevilla, von C. Maschek, 1. Theil 30 kr. 2. detto 2. Theil $30 \mathrm{kr}$. 3. detto 3. Theil $30 \mathrm{kr}$. 4. Deutsche Tänze aus: der diebischen Elster (la gazza ladra) $20 \mathrm{kr}$. [...] Angeführte Tänze sind auch für das Forte-Piano zu 4 Bänden [Händen], für Flöte mit oder ohne Guitarre-Begleitung, wie auch für andere Instrumente zu baben.

Source: LZ (IB), 30 Mar 1821, 410; 3 Apr 1821, 436; 6 Apr 1821, 440.

In der deutschen Gasse Nro. 187 im 3. Stock ist zu haben: [...] Deutsche Tänze sammt Trio's, nach Rossini's Barbier von Sevilla, für die Carnevalls-Zeit wäbrend des Congresses in Laibach; 3 Theile, für das Piano-Forte, wie auch für verschiedene andere Instrumente.

Source: LZ (IB), 15 May 1821, 632; 18 May 1821, 640; 22 May 1821, 659. 


\subsection{Louis von Lazarini}

Bey Herrn Korn, Buchbändler zu Laibach, sind zu haben: die, mit allgemeinem Beyfall aufgenommenen und dem Vergnügen der edlen Bewohner zu Laibach gewidmeten Redout-Deutschen mit Coda, componirt und für das Pianoforte eingerichtet von Louis Baron v. Lazarini, in 2 Abtheilungen, jede á 30 Kreutzer. Source: LZ (IB), 1 Mar 1822, 280; 5 Mar 1822, 288.

\subsection{Caspar Maschek / D. Weber / K. W. S.}

Bey C. Maschek, nächst der Schusterbrücke Nro. 234 im 3. Stock, ist neu zu haben: Deutsche Tänze für den Carneval 1822: aus Rosini's [sic] Cenerentola, von C. Maschek, für das Fortep. 30 kr. zu 4 Hände 1 fl.; aus Don Juan, von D. Weber für das Fortep. 30 kr. zu 4 Hände 1 fl; Glöckerl-Deutsche, von K. W. S. für das Fortep. 30 kr. zu 4 Hände 1 fl. Dieselben für Flöte, mit und ohne Begleitung.

Source: LZ (IB), 11 Jan 1821 [=1822], 58; 15 Jan 1822, 66.

\subsection{Caspar Maschek / Eduard Hysel}

Zwischen den 1. und 2. Akte werden die, für den Fasching 1822 im Redouten Saale zu produzirenden deutschen Tänze aus der Rossinischen Oper: Cenerentola, componirt von Herrn Carl Maschek, gemacht werden.

Source: NMS, Comedien-Zettel Sammlung, 1821/22, 6 Jan 1822.

Bey C. Maschek, nächst der Schusterbrücke Nro. 234 im 3. Stock, ist neu zu haben: Deutsche Tänze für den Carneval 1822: aus Rossini's Eduard und Christine, für Forte-Piano zu 2 Hände 30 kr. zu 4 Hände 1 fl.; aus Rossini's Cenerentola, [für Forte-Piano zu 2 Hände 30 kr. zu 4 Hände 1 fl.]. Deutsche von Ed. Hysel, für das Forte-Piano [zu 2 Hände 30 kr. zu 4 Hände 1 fl.] Dieselben für Flöte, mit und ohne Begleitung.

Source: LZ (IB), 22 Jan 1822, 102; 25 Jan 1821 [=1822], 110.

Bey C. Maschek, nächst der Schusterbrücke Nro. 234 im 3. Stock, ist neu zu haben: [...] Glöckerl-Deutsche und Deutsche aus Eduard und Christine für einen Czakan à $20 \mathrm{kr}$.

Source: LZ (IB), 12 Feb 1822, 175; 15 Feb 1822, 192.

Copy: Deutsche aus Rossini's Eduard und Christine für den Carneval 1822 von C. Mascheck für das Forte Piano. Laibach zu finden bey C. Mascheck. 30 $k r$ NUK (Ms.).

\subsection{Leopold Ferdinand Schwerdt}

Zwischen den 2ten und 3ten Akte werden die, für die Theater-Bälle bestimmten Deutschen-Tänze von der Composition des Herrn Leopold Schwerdt, produziret werden.

Source: NMS, Comedien-Zettel Sammlung, 1821/22, 7 Jan 1822.

Heute Sonntag den 13. Jäner 1822 wird im Theater der erste maskierte Ball abgehalten werden. Für ein woblbesetztes Orchester, so wie für ganz neue Tänze 
von der Komposition des Herrn Leopold Schwerdt ist gehörig gesorgt worden.

Source: NMS, Comedien-Zettel Sammlung, 1821/22,13 Jan 1822.

\subsection{Joseph Wilde}

Bey C. Maschek, nächst der Schusterbrücke Nro. 134 im 3. Stock, ist neu zu haben: Cotillions, Redoutdeutsche, für das Fortep. von [Joseph] Wilde, aus den Opern der Freyschütze [C. M. von Weber] und der schönen Müllerinn [G. Paisiello] $1 \mathrm{f}$.

Source: LZ (IB), 24 Sep 1822, 1234; 27 Sep 1822, 1240.

\subsection{Louis von Lazarini}

Bey W. H. Korn ist zu haben: VIII Laibacher Redout-Deutsche mit Trio's und Coda, für das Forte-Piano componirt von Herrn Louis Baron v. Lazarini, Lythographirt. 1823. Preis $36 \mathrm{kr}$.

Source: LZ (IB), 24 Jan 1823, 93; 28 Jan 1823, 106; 31 Jan 1823, 118; 7 Feb 1823, 145.

Acht neue Redout-Deutsche für das Pianoforte mit Trios und Coda, auf den Carneval 1823, componirt von Baron v. Lazarini, sind beym Gefertigten um den Preis von 1 fl. 30 kr.WW. zu haben. Joseph Franz Kaiser, zum Kronprinzen von Oesterreich. Source: GZ (SIB), 18 Jan 1823, [5]; 25 Jan 1823, [10].

\subsection{Louis von Lazarini}

Bey W. H. Korn, Buchbändler in Laibach, sind zu haben: VI Laibacher RedoutDeutsche für das Piano-Forte von Louis Baron v. Lazarini, zweyte Abtheilung. Kostet $30 \mathrm{kr}$.

Source: LZ (IB), 4 Feb 1823, 126; 7 Feb 1823, 142; 11 Feb 1823, 158.

\subsection{Leopold Cajetan Ledenig}

In dem Glashandlungsgewölbe auf dem Platze Haus Nr. 264, sind 2 Partien für den Carneval 1823 verfaßte Laibacher Redout-Deutsche mit Trio's von L. C. Ledenegg um folgende Preise zu haben: Jede Partie (6 deutsche Tänze enthaltend) kostet: fur das Pianoforte 40 kr.; für Flöte und Guitarre 40 kr.; und für 2 Violinen und $B a \beta 1 f$.

Source: LZ (IB), 10 Jan 1823, 32; 14 Jan 1823, 42; 17 Jan 1823, 55.

\subsection{Caspar Maschek}

Bey C. Maschek, nächst der Schusterbrücke Nro. 137 im 3. Stock, ist neu zu haben: Sech deutsche Tänze sammt Trio's nach Rossini’s beliebter Oper: Zelmira, von C. Maschek, für die Carnevalszeit 1823, für das Forte-Piano: 40 kr; für das Forte-Piano zu 4 Hände 1 f. 20 kr.; für den Czakan 20 kr.; für Flöte und Guitarre 40 kr., für 2 Viol. u. Baß 1 fl.

Source: LZ (IB), 3 Jan 1823, 4; 7 Jan 1823, 22; 24 Jan 1823, 93; 28 Jan 1823, 106. 


\subsection{Leopold Ferdinand Schwerdt}

Zwischen den Akten werden die für diesen Fasching zu den Theater-Bällen von Herrn Schwerdt neu komponirten deutschen Tänze, gemacht werden.

Source: NMS, Comedien-Zettel Sammlung, 1822/23, 9 Jan 1823.

Theater-Ball- und Abonnement-Nachricht. [...] Die für diesen Fasching bestimmten Tänze sind ganz neu von Herrn Schwerdt componirt worden.

Source: NMS, Comedien-Zettel Sammlung, 1822/23, 12 Jan 1823.

\subsection{Louis von Lazarini}

In den Zwischenakten werden die für dieses Jahr von Herrn Baron von Lazzarini neu componirten Redouten-Deutsche und Ländler vorgetragen.

Source: NMS, Comedien-Zettel Sammlung, 1823/24, 1 Jan 1824.

Neue Redout-Deutsche. Es wird bekannt gemacht, daß in der Licht'schen Buchbandlung die heurigen Redout-Deutschen, die erste und zweyte Abtheilung, und auch die Ländler vom Herrn Baron von Lazarini, für das Piano-Forte arrangirt, zu haben sind. Jedes Exemplar Deutsche, so wie auch die Ländler, kosten fehlerfrey copirt $24 \mathrm{kr}$.

Source: LZ (IB), 9 Mar 1824, 349; 12 Mar 1824, 369; 16 Mar 1824, 405.

\subsection{Leopold Cajetan Ledenig}

Neue Redout-Deutsche. Die von L. Ledenig für den Carneval 1824 verfaßten, dem Vergnügen der Bewohner Laibachs gewidmeten 6 neuen RedoutDeutschen mit Trio's, sind vom 19. d. M. angefangen, an gewöbnlichen Tagen in dem Glashandlungs-Gewölbe im Kaufmann Alborgettischen Hause Nro. 265 auf dem Platze, an Sonn- und Feyertagen aber im Apotheker Wagner'schen Hause Nr. 4 auf dem Platze, rein geschrieben gegen nachstehende Preise zu haben: Im Pianoforte Auszuge um 40 kr.; Für Flöte (oder Violin) und Guitarre um 40 kr.; Für Czakan und Guitarre 40 kr.; Für 2 Violinen und $B a \beta$ um $1 \mathrm{f}$.

Source: LZ (IB), 16 Jan 1824, 72; 20 Jan 1824, 82; 23 Jan 1824, 98.

Copy: 6 Deutsche mit Trio's für die Laÿbacher Redout im Carneval 824, für das Piano Forte von L. C. Ledeneg. Slavic Library Ljubljana (Slovanska knjižnica) (Ms.), Collection Jožefina Terpinc.

\subsection{Michael Maier}

Morgen Sonntag den 10. Januar beginnt in dem hiesigen landständischen Theater der erste maskirte Ball. [...] Zur Eröffnung der Theater-Bälle hat Herr Michael Maier, Kapellmeister des hiesigen ständ. Theaters neue deutsche Tänze componirt.

Source: NMS, Comedien-Zettel Sammlung, 1823/24, 9 Jan 1824; 11 Jan 1824. 


\subsection{Georg Micheuz}

VII neue Schießstatt-Deutsche mit Trio's von Georg Micheuz, für den Carneval des Jahres 1824 verfaßt und dem Wohlgeb. Herrn Johann Nep. Hradeczky, Bürgermeister und ständischen Verordneten zu Laibach ehrfurchtsvoll gewidmet, sind täglich in dem Glashandlungs-Gerwölbe im Kaufmann Alborgettischen Hause Nr. 265 auf dem Platze, rein geschrieben um nachstehende Preise zu haben, als: für das Pianoforte um 40 kr., für Flöte (oder Violin) und Guitarre um 40 kr., für zwey Violinen und Baß um 40 kr. Ferner sind zu haben: Sechs Schießstadt-Ländler.

Source: LZ (IB), 17 Feb 1824, 238; 20 Feb 1824, 245-6; 24 Feb 1824, 273.

\subsection{Louis von Lazarini}

Um einem hochverehrten Publikum einen vergnügten Abend zu verschaffen, werden während den Zwischenakten, die diesjährigen neu Componirten Redout-Deutschen Produzirt werden. Erste Parthie, ist von Herrn Baron. v. Lazarini. - Zweyte Parthie, von Herrn Ledenek.

Source: NMS, Comedien-Zettel Sammlung, 1824/25, 13 Jan 1825.

Während den Zwischenakten wird die zweyte Parthie der Redout-Deutschen des Herrn Baron v. Lazarini, und die neu componirten Redout-Deutschen des Herrn Micheuz, produzirt werden.

Source: NMS, Comedien-Zettel Sammlung, 1824/25, 15 Jan 1825.

Die vom Herrn Baron von Lazarini ganz neu componirten und eigens für's Fortepiano eingerichteten zwey Abtheilungen Redout-Deutsche für den Carneval 1825, sind in der Licht'schen Buchhandlung zu haben. Jede Abtheilung kostet $20 \mathrm{kr}$.

Source: LZ (IB), 1 Feb 1825, 180; 4 Feb 1825, 220; 8 Feb 1825, 252.

Copy: 6 Redout Deutsche mit Trio's für den Carneval 825 zu Laÿbach componirt und für's Piano Forte eingerichtet von Louis Baron von Lazarini. $2^{\text {te }}$ Abtheilung. NUK (Ms.).

\subsection{Leopold Cajetan Ledenig}

Um einem hochverehrten Publikum einen vergnügten Abend zu verschaffen, werden während den Zwischenakten, die diesjährigen neu Componirten Redout-Deutschen Produzirt werden. Erste Parthie, ist von Herrn Baron. v. Lazarini. - Zweyte Parthie, von Herrn Ledenek.

Source: NMS, Comedien-Zettel Sammlung, 1824/25, 13 Jan 1825.

Neue Redout-Deutsche. Die Laibacher Redout-Deutschen für das Jahr 1825, von Leopold Ledeneg, (7 Stück), sind von heute an im Clavier-Auszuge täglich in der Landschafts-Apotheke nächst der Schusterbrücke, um den Betrag von 40 kr. zu haben. Für Arrangements auf andere Instrumente beliebe man eben daselbst vorläufg die Bestellung zu machen. Laibach am 18. Jänner 1825.

Source: LZ (IB), 18 Jan 1825, 93; 21 Jan 1825, 107-8; 25 Jan 1825, 142. 


\subsection{Caspar Maschek}

Am Platz Nr. 5 ist neu zu haben: 6 neue deutsche Tänze sammt Trio's, nach den beliebten Melodien aus Mayerbaers neuester Oper, Il Crociato in Egitto, im leichten und angenehmen Style für das Pianoforte verfaßt von C. Maschek, zu $40 \mathrm{kr}$.

Source: LZ (IB), 25 Jan 1825, 146; 28 Jan 1825, 169; 1 Feb 1825, 189.

\subsection{Georg Micheuz}

Während den Zwischenakten wird die zweyte Parthie der Redout-Deutschen des Herrn Baron v. Lazarini, und die neu componirten Redout-Deutschen des Herrn Micheuz, produzirt werden.

Source: NMS, Comedien-Zettel Sammlung, 1824/25, 15 Jan 1825.

In der Licht'schen Buchhandlung in Laibach sind zu haben: Sechs OriginalLaibacher-Redout-Deutsche für den Carneval 1825, componirt und für das Pianoforte eingerichtet von Georg Micheuz, 24 kr. Sechs Original-LaibacherSchießstadt-Deutsche pro 1825, ebenfalls für das Pianoforte eingerichtet von eben demselben, $26 \mathrm{kr}$.

Source: LZ (IB), 18 Jan 1825, 93; 21 Jan 1825, 108; 25 Jan 1825, 142.

Copy: 6 Original Laibacher-Redout-Deutsche für den Carnevall des Jahrs 1825 Componirt dem Verehrungswürdigen Publicum gewidmet und für das Piano Forte eingerichtet von Georg Micheuz. Slavic Library Ljubljana (Slovanska knjižnica) (Ms.), Collection Jožefina Terpinc.

Copies: VI Original Laibacher Schiessstatt Deutsche für den CARNEVAL des Jahres 1825 componirt und für das Piano Forte eingerichtet von Georg Miheuz. $1^{\text {tes }}$ Werk. WIEN gedruckt im lithograph. Institute nächst der k. k. Burg $N^{\circ} 2$. A-Wgm XV 50487 (Q19587); NUK (incomplete).

\subsection{Martin Schuller}

Copy: 6 Laibacher Redout-Deutsche mit Trios für den Carneval 825 für das Piano-Forte. NUK (Ms.).

\subsection{Leopold Cajetan Ledenig / Carl Suppantschitsch}

Sechs neue Redout-Deutsche sammt Trio's, für Laibach und Klagenfurt für den Carneval des Jahres 1826, bearbeitet von Leopold Cajet. Ledenig, sind im Pianoforte-Auszuge zu haben in der Landschafts-Apotheke nächst der Schusterbrücke um den Betrag von 40 kr.C.M.

Ebendaselbst sind zu kaufen 6 neue Laibacher Schießstadt-Deutsche sammt Trio's für den Carneval 1826, componirt von Carl Suppantschitsch im PianoforteAuszuge um 30 kr.C.M.

Source: LZ (IB), 17 Jan 1826, 107; 20 Jan 1826, 116; 24 Jan 1826, 135. 


\subsection{Georg Micheuz}

Während den Zwischen-Akten werden die Laibacher Schießstatt Deutschen für den Karneval 1826. Werden produzirt.

Source: NMS, Comedien-Zettel Sammlung, 1825/26, 6 Jan 1826.

Bey W. H. Korn sind zu haben: Sechs neue brillante Original-LaibacherSchießstatt-Deutsche mit Coda, für den Carneval des Jahres 1826 componirt, dem Wohlgebornen Herrn Johann Nep. Hradeczky Hochachtungsvoll gewidmet, und für das Pianoforte eingerichtet von Georg Micheuz. Preis $36 \mathrm{kr}$.

Source: LZ (IB), 31 Jan 1826, 214; 3 Feb 1826, 239; 7 Feb 1826, 258.

Copies: Sechs neue brillante Original Laibacher-Schiessstatt-Deutsche mit Coda für den Carneval des Jahres 1826. Componirt, dem Wohlgebornen Herrn Joh. Nep. Hradeczky Hochachtungsvoll gewidmet, und für das Pianoforte, eingerichtet von GEORG MIHEUZ. 14tes Werk. Wien, bey Cappi und Comp. No. 79. Pr. 36 x.C.M. /1 f. 15 x.W.W.A-Wgm XV 50485 (Q19588); NUK.

\subsection{Louis von Lazarini}

Bey Joseph Franz Kaiser ist ganz neu erschienen und zu haben, als: [...] Sechs Laibacher Schießstatt-Deutsche mit Trio's für den Carneval 1827. Componirt, und allen Herren Schützen und Jägern Laibachs hochachtungsvoll gerwidmet von Luis Baron v. Lazarini. 30 kr.

Source: GZ (SIB), 20 Jan 1827, [27]; 25 Jan 1827, [26]; 6 Feb 1827, [20]; 10 Feb 1827, [21]; 24 Feb 1827, [26].

Im Zeitungs-Comptoir zu Laibach sind zu 30 kr.C.M. zu haben: Neue lithographirte Sechs Laibacher Schießstatt-Deutsche mit Trio's für den Carneval 1827 componirt und allen Herren Schützen und Jägern Laibachs hochachtungsvoll gewidmet von Ihrem Mitgliede Louis Baron v. Lazarini.

Source: LZ (IB), 16 Jan 1827, 96; 19 Jan 1827, 116; 23 Jan 1827, 130.

Copies: SECHS Laibacher Schiessstatt Deutsche mit Trios für den Carneval 1827 componirt und allen Herrn Schützen und Jägern Laibachs hochachtungsvoll gewidmet von Ihrem Mitgliede LOUIS B ${ }^{A R O N}$ VON LAZARINI. Lithogra: bey Ios. F. Kaiser in Gratz. A-Wgm XV 4857 (Q 19499); NUK.

\subsection{Leopold Cajetan Ledenig}

Pränumerations-Anzeige. Um die, von Leopold Cajet. Ledenig für den Carneval 1827 bereits vollendeten Laibacher Redout-Deutschen mit Trio's wieder im lithographirten Pianoforte-Auszuge liefern zu können, und für die dießfälligen bedeutenden Kosten doch einigermaßen gesichert zu seyn, werden die Liebhaber deutscher Tanzmusik hiermit geziemend eingeladen, hierauf gegen Erlag von 30 kr.C.M. für ein Exemplar in dem hierortigen Zeitungs-Comptoir sich gefälligst pränumeriren zu wollen. Da die Ausgabe der lithographirten Deutschen von der binlänglichen Zahl der Abnehmer abhängt, so haftet in dem Falle, als dieses Vorbabens wegen der unbedeckten dießfälligen Kosten nicht zu Stande kommen 
sollte, für die richtige Zurückgabe der eingelegten Pränumerations-Beträge das Ig. Edel v. Kleinmayr'sche Zeitungs-Comptoir.

Source: LZ, 24 Nov 1826, 2286; 28 Nov 1826, 2270; 5 Dec 1826, 2310.

Es wird hiemit zur Kenntniß gebracht, daß die Pränumeration auf Ledenig's lithographirte Laibacher Redout-Deutsche pro 1827 (im Pianoforte-Auszuge, das Exemplar zu 30 kr.C.M.) im 15 d. M. geschlossen, und später der allgemeine Verkaufspreis mit $40 \mathrm{kr}$. für das Exemplar bestimmt werden wird.

Source: LZ (IB), 5 Jan 1827, 52; 9 Jan 1827, 60; 12 Jan 1827, 76.

Herrn Ledenig's neue Laibacher Redout-Deutsche sind im lithographirten Pianoforte-Auszuge bereits angelangt. Die (P. T.) Herren Pränumeranten wollen dieselben in den unterzeichneten Zeitungs-Comptoir abholen lassen, und die allenfalls noch unberichtigten Pränumerations-Beträge ebendaselbst bey Empfang gefälligst erlegen. Der nun eintretende Verkaufspreis außer der Pränumeration ist 40 kr.C.M. Zeitungs-Comptoir.

Source: LZ (IB), 19 Jan 1827, 116; 23 Jan 1827, 130; 26 Jan 1827, 136.

Bey Joseph Franz Kaiser ist ganz neu erschienen und zu haben, als: [...] Sechs Laibacher Redout-Deutsche sammt Trios für den Carneval dieses Jabres 1827 verfaßt. Für das Pianoforte eingerichtet, und dem hochgebornen Fräulein Antoinette Freyinn von Schmidtburg, hochachtungsvoll gewidmet von Leopold Cajetan Ledenig. $30 \mathrm{kr}$.

Source: GZ (SIB), 20 Jan 1827, [27]; 25 Jan 1827, [26]; 6 Feb 1827, [20]; $10 \mathrm{Feb}$ 1827, [21]; $24 \mathrm{Feb}$ 1827, [26].

Copies: VI LAIBACHER REDOUT DEUTSCHE SAMT TRIO'S für den Carneval des Jahres 1827 VERFASST, FÜR DAS PIANO-FORTE EINGERICHTET, UND DEM hochgebornen Fräulein Antoinette Freyin von Schmidburg hochachtungsvoll gewidmet von LEOPOLD CAJETAN LEDENIG. Lithograph: bei Joseph Fr. Kaiser. Preis 30 x. C.M. A-Wgm XV 4860 (Q19501); NUK.

\subsection{Georg Micheuz}

Bey Cappi und Czerny, privil. Kunst- und Musikalienbändlern, am Graben Nr. 1134; sind erschienen, und bey G. Lichtl in Pesth um denselben Preis zu haben: Original Laibacher Schießstatt-Deutsche, für den Carneval des Jahres 1827, componirt und für das Pianoforte eingerichtet von Georg Mibeuz. Erste und zweyte Lieferung zu 1 fl. Wiener-Währung.

Source: WZ, 23 Feb 1827, 228.

Copy: ORIGINAL Laibacher Schiessstatt Deutsche für den Carneval des Jahres 1827 componirt von GEORG MIHEUZ. $1^{\text {te }}$ Abtheilung. (Eigenthum der Verleger) No. 253. Wien, bey Cappi und Czerny, Graben, 1134. Pr. 30 x.CM. A-Wst Mc-20824.

Copy: ORIGINAL Laibacher Schiessstatt Deutsche für den Carneval des Jahres 1827 componirt von GEORG MIHEUZ. $2^{\text {to }}$ Abtheilung. (Eigenthum der 
Verleger) No. 254. Wien, bey Cappi und Czerný, Graben, 1134. Pr. 30 x.CM. A-Wgm XV 8861 (Q19590).

\subsection{Johann Carl Fischer von Wildensee}

Copy: VI Laibacher Redout-Deutsche für das Piano-Forte auf den Carneval des Jahres 1828 componiert und dem wohlgebornen Fräulein ADELE von SCHWARZMANN achtungsvoll gewidmet von Joh. Carl Fischer Edlen von Wildensee. NUK (Ms.).

\subsection{Leopold Cajetan Ledenig}

Pränumeration auf Ledenig's neue Laibacher Redout-Deutsche, für den Carneval des Jahres 1828. Wer auf die von Ledenig verfaßten, sechs neuen Redout-Deutschen sammt Trio's, welche bis 1. Jänner 1828, im lithographirten Piano-Forte-Auszuge erscheinen werden, mit 30 kr.C.M. für das Stück zu pränumeriren wünscht, wolle sich dießfalls an dieses Zeitungs-Comptoir wenden. Auch können daselbst Bestellungen auf verschiedene Arrangements dieser Deutschen in geschriebenen Exemplaren, als für 2 Violinen und Baß um 1 fl.; für 1 Flöte (oder Czakan) und Guitarre um 40 kr.; für Harmonie von 6 bis 8 Blasinstrumenten um $2 \mathrm{fl}$. $30 \mathrm{kr}$. bis $3 \mathrm{fl}$. mündlich oder in portofreyen Briefen gemacht werden. Der Ladenpreis für die lithographirten Stücke ist mit 1. Jänner 1828, à 40 kr. Conventions-Münze.

Source: LZ (IB), 27 Nov 1827, 1906; 7 Dec 1827, 1906; 11 Dec 1827, 1918. Heute werden die vom Herrn Leopold Ledenig verfaßten diesjährigen neuen Redout-Deutschen, und zwar vor dem Anfange des Stückes alle sechs obne Unterbrechung vom gut besetzten Orchester vorgetragen, in den Zwischenacten aber abgetheilt wiederholt werden.

Source: NMS, Comedien-Zettel Sammlung, 1827/28, 3 Jan 1828.

Jene respective Herren, welche auf Ledenig's neue Laibacher Redout-Deutsche, entweder im Zeitungs-Comptoir, oder auf den Separat-Subscriptionsbogen prä[n]umerirt haben, werden um zu den bereits eingelangten lythographirten Piano-Forte-Auszügen leichter und schneller zu gelangen, geziemend ersucht, dieselben in diesem Zeitungs-Comptoir gefälligst abholen zu lassen. Ebendaselbst erliegen auch die bestellten geschriebenen Exemplare für Flöte und Guitarre. Von nun an tritt für die nicht pränumerirten lythographirten Exemplare, welche fortwährend in diesem Zeitungs-Comptoir zu haben seyn werden, der Ladenpreis mit $40 \mathrm{kr}$.C.M. pr. Stück ein.

Source: LZ (IB), 8 Jan 1828, 12; 10 Jan 1828, 14; 12 Jan 1828, 21.

Bey Leopold Paternolli, am Platz, Nr. 259, in Laibach sind folgende Neuigkeiten zu haben [...] Laibacher-Redout-Deutsche für 1828, für Piano-Forte, von Leopold Ledenig, à $40 \mathrm{kr}$.

Source: LZ (IB), 15 Jan 1828, [24].

Copy: Sechs Laibacher Redout Deutsche SAMT TRIOS für den Carneval des 
Jahres 1828 verfasst, für das PLANO-FORTE eingerichtet und der woblgebornen Frau Marie Wagner geborne Schmidhammer GUBERNLAL-RATHES GATTINN hochachtungsvoll gewidmet von Leopold Cajetan Ledenig. Lith. u. gedr. [in Graz] Bey Ignatz Hofer Feuerbachgasse No 831. NUK.

\subsection{Franz Seraphin Nepozitek}

Die von dem Herrn Franz $N \_k$ hinterlassenen, dem hochgebornen Fräulein $E$. Freyinn von Sch. gewidmeten, bey Kaiser in Grätz lithographirten Laibacher Redout-Deutschen für 1828, im Clavier-Auszuge, deren Ertrag einem woblthätigen Zwecke gerwidmet ist, sind im Zeitungs-Comptoir das Stück zu 40 kr.C.M. zu haben. Edel v. Kleinmayr'sches Zeitungs-Compt.

Source: LZ (AB), 9 Feb 1828, 138; LZ (IB), 9 Feb 1828, 74.

Bey J. F. Kaiser in Grätz, ist neu erschienen, und bey Anton Paterno, Kunsthändler, am neuen Markt Nr. 1064, zu haben: Die beliebten Laibacher Redout-Deutschen für das Pianoforte componirt von Franz Seraph. Nepozitek. Preis 36 kr. Conv. Münze. Der Ertrag isteinem wohlthätigen Zwecke gewidmet. Source: WZ, 20 Mar 1828, 308.

Copy: LAIBACHER REDOUT DEUTSCHE gewidmet dem hochwoblgebornen Fräulein Elise FREYIN V. SCHMIDBURG von FRANZ SERAPH NEPOZITEK. Lithographirt bei Joseph Franz Kaiser in Grätz. Der Ertrag ist einem wohlthätigen Zweke gewidmet. A-Wgm XV 4915 (Q19671).

Copy: LAIBACHER REDOUT DEUTSCHE gewidmet dem hochwoblgebornen Fräulein Elise FREYIN V. SCHMIDBURG von FRANZ SERAPH. NEPOZITEK. NUK (Ms.).

\subsection{Leopold Ferdinand Schwerdt}

Zwischen den Akten werden Deutsche und Walzer vorgetragen, für die Laibacher bürg. Schießstätte componirt, und den P. T. Herren Schützen gewidmet von L. F. Schwerdt. Diese Tänze sind auf der St. Peters-Vorstadt Nro. 21 im 1sten Stock für alle beliebigen Instrumente zu haben.

Source: NMS, Comedien-Zettel Sammlung, 1827/28, 6 Dec 1827.

Bey Leopold Paternolli, am Platz, Nr. 259, in Laibach [...] Folgendes aber ist bey ihm in Manuscripten zu haben, als: von Ferd. Leopold Schwerd, 6 Deutsche mit Trio's für das Piano-Forte, der Schützengesellschaft zu Laibach, für den Carneval 1828 gewidmet, $35 \mathrm{kr}$.

Source: LZ (IB), 15 Jan 1828, [24].

\subsection{Carl Suppantschitch}

Bey L. Paternolli in Laibach, am Platze, Nr. 259, sind folgende Neuigkeiten angelangt, als: [...] Sechs Deutsche sammt Trio's, der Laibacher SchützenGesellschaft gewidmet von C. Suppantschitsch, à $30 \mathrm{kr}$.

Source: LZ (IB), 7 Feb 1828, 66; 9 Feb 1828, 68; 12 Feb 1828, 72. 


\subsection{8 [Author not named]}

Vor Anfang des Stückes und in den Zwischenakten werden ganz neue RedoutDeutsche von einem Ungenannten durch ein zablreich besetztes Orchester executiert werden.

Source: NMS, Comedien-Zettel Sammlung, 1827/28, 8 Jan 1828.

\subsection{Johann Carl Fischer von Wildensee}

Im hiesigen Zeitung-Comptoir wird mit $30 \mathrm{kr}$. pr. Exemplar Pränumeration angenommen auf neue gestochene Redout-Deutsche pro 1829, im Piano-ForteAuszuge, von J. C. Fischer Edler v. Wildensee.

Source: LZ (Anh.), 28 Oct 1828, 1000; LZ (IB), 23 Oct 1828, 986; 25 Oct 1828, 994; 30 Oct 1828, 646; 1 Nov 1828, 650; 11 Dec 1828, 727; 13 Dec $1828,731$.

Bei Leopold Paternolli, in Laibach am Platze, Nr. 259, sind folgende Neuigkeiten zu haben: [...] Laibacher Redout-Deutsche pro 1829, für das Forte-Piano von Fischer Edlen v. Wildensee, gestochen à $40 \mathrm{kr}$.

Source: LZ (IB), 15 Jan 1829, 28.

Bey A. Pennauer, Kunst-und Musikalienbändler in Wien, am Graben Nr.1122, ist zu haben, wie auch bey C. Lichtl in Pesth, bey J. Niemirowsky in Lemberg, bey Carl Streidig und Meidinger in Preßburg: Neue Tanz-Musikalien. Fischer, Laibacher Redout-Deutsche sammt Trios für das Pianoforte. Preis 30 kr.C.M.

Source: WZ, 19 Feb 1829, 179; 25 Feb 1829, 206; 2 Mar 1829, 224.

Copies: LAIBACHER REDOUT-DEUTSCHE sammt Trios für den Carneval 1829 componirt für das PIANO-FORTE eingerichtet und dem Woblgebornen Fräulein WILHELMINE V. PRAHL achtungsvoll gewidmet von J. C. FISCHER Edlen von Wildensee. [Wien: A. Pennauer, no. 412.] A-Wn M.S.36525; NUK (Ms.).

\subsection{Leopold Cajetan Ledenig}

Sechs neue Laibacher Redout-Deutsche mit Trio's für den Carneval des Jahres 1829. Verfaßt und für das Piano-Forte eingerichtet von Leopold Cajetan Ledenig (Achter Jahrgang.) Auf diese, im schön lithographirten Piano-ForteAuszuge erscheinenden neuen Produkte, für deren Gehalt die von dem Herrn Verfasser seit 7 Jahren in diesem Fache gelieferten, stets beyfällig aufgenommenen Bearbeitungen sprechen, wird in diesem Zeitungs-Comptoir mit 30 kr.C.M. pr. Stück, Pränumeration angenommen.

Source: LZ (IB), 4 Nov 1828, 654; 6 Nov 1828, 658; 20 Nov 1828, 686. Nachdem die lithographirten Piano-Forte-Auszüge der neuen Redout-Deutschen des Herrn Ledenig für das Jahr 1829, in den ersten Tagen des kommenden Monates Jänner bestimmt einlangen werden; so bringt das Zeitungs-Comptoir biermit zur Kenntniß, daß die bereits angezeigte Pränumeration auf diese Deutschen mit 30 kr. pr. Exemplar nur noch bis zum 6. Jänner 1829 dauern, 
und in diesem Zeitungs-Comptoir angenommen werde, indem nach Verlauf dieser Zeit der Ladenpreis zu 40. kr. pr. Exemplar eintritt. Laibach am 10. December 1828.

Source: LZ (IB), 13 Dec 1828, 731; 27 Dec 1828, 790; 30 Dec 1828, 794. Bei Leopold Paternolli, in Laibach am Platze, Nr. 259, sind folgende Neuigkeiten zu haben: [...] Laibacher Redout-Deutsche pro 1829, für das Forte-Piano, von Ledenig, lythographirt à $40 \mathrm{kr}$.

Source: LZ (IB), 15 Jan 1829, 28.

Bey F. J. Kaiser in Grätz ist so eben erschienen, und bey Anton Paterno, Kunsthändler am neuen Markte Nr. 1064, zu haben: [...] Ledenig; L. C., Laibacher Redout-Deutsche für das Pianoforte. 30 kr. C.M.

Source: WZ, 9 Feb 1829, 138; 18 Feb 1829, 275; 21 Feb 1829, 189.

\subsection{S. T. Thomaschovitz}

Bei L. Paternolli am Platze, sind 6 neue Schießstatt-Deutsche für den Carneval 1829, im Piano-Forte-Auszuge von S. T. Tomaschovitz, à $40 \mathrm{kr}$. das Exemplar zu haben.

Source: LZ (AB), 20 Jan 1829, 58; LZ (IB), 22 Jan 1829, 41.

VI Neue Deutsche mit Trios's für den Carneval 1829. Componirt von S. T. Thomaschovitz, sind im biesigen Zeitungs-Comptoir à $40 \mathrm{kr}$. zu haben.

Source: LZ (Anh.), 19 Jan 1829; LZ (IB), 21 Feb 1829, 108; 24 Feb 1829, 112.

\subsection{9 [Author not named]}

Bei Leopold Paternolli, in Laibach am Platze, Nr. 259, sind folgende Neuigkeiten zu haben: [...] Laibacher Redout-Deutsche pro 1829, für Guitarre und Flöte, geschrieben à $40 \mathrm{kr}$.

Source: LZ (IB), 15 Jan 1829, 28.

\subsection{Louis von Lazarini}

Bei Leopold Paternolli am Platz in Laibach, wird Pränumeration angenommen mit 24 kr. für jedes einzelne Stück, und mit 1 fl. C.M. für alle drey zusammen, auf: 6 Laibacher Redout-Deutsche pro 1830, für das Piano-Forte sammt Trio. 6 Laibacher Schießstatt-Deutsche pro 1830, für das Piano-Forte sammt Trio. 12 Laibacher Schießstatt-Ländler zu Cottilions pro 1830, für das Piano-Forte sammt Trio. Alle diese Deutsche sind von dem hochgebornen Herrn Baron Louis v. Lazarini, componirt und eingerichtet. Die Pränumeration dauert bis zum 15. Jänner; nach Beendigung der Pränumeration tritt der erhöhte Ladenpreis von 36 kr. für jedes Stück ein. Den hiesigen verehrten Musikfreunden ist binlänglich der bochgeschätzte Herr Autor bekannt, als daß man erst darübervon Seite des Verlegers ein Mehreres sagen zu müssen nöthig hätte; welcher keine Mühe noch Kosten sparen wird, um mit Eleganz das Aeußere, so wie auch das Uebrige auszustatten. 
Source: LZ (Anh.), 29 Dec 1829, 1128; LZ (IB), 2 Jan 1830, 4; LZ (AB), 5 Jan 1830, 14.

In der lithographischen Verlags-Handlung des Joseph Franz Kaiser ist neu erschienen, und das Exemplar um 24 kr.CM. zu haben: Gut componirte Deutsche sammt Trio für das Pianoforte, für den Carneval 1830, von Baron von Lazarini, gewidmet der Frau Josephine von Taubenberg. I. Abtheilung.; 6 Deutsche sammt Trio für den Carneval 1830, von Baron von Lazarini, gewidmet der Frau Marie Edlen v. Kreuzberg. II. Abtheilung.; 13 Ländler zu Cottilions für den Carneval 1830, von Baron von Lazarini, gewidmet dem Fräulein Wilhelmine Prabl.

Source: GZ (SIB) 7 Jan 1830, 32; 14 Jan 1830, 63; 19 Jan 1830, 88; 25 Jan 1830, 108; 26 Jan 1830, 120; 18 Feb 1830, 229.

Bei Leopold Paternolli, sind erschienen: Sechs Laibacher Redout-Deutsche, sechs Laibacher Schießstatt-Deutsche und 13 Ländler zu Cottillons, für den Fasching 1830; componirt und für das Piano-Forte eingerichtet von dem hochgebornen Hrn. Louis Baron v. Lazzarini; der Preis für alle drei Stücke zusammen ist $1 \mathrm{f}$. $30 \mathrm{kr}$, einzeln à $36 \mathrm{kr}$.

Source: LZ (AB), 19 Jan 1830, 46; 23 Jan 1830, 54; 26 Jan 1830, 59.

Copy: VI LAIBACHER REDOUT DEUTSCHE mit Trios für das Fortepiano für den Carneval 1830 componirt und mit Hochachtung gewidmet der Woblgebornen Frau MARIE EDLE VON KREUTZBERG VON LOUIS BARON VON LAZARINI. Gedruckt bei Joseph Franz Kaiser in Graz. Verlegt von Paternolli in Laibach. Zu haben auch in Capodistria und Görz bei Paternolli. NUK.

\subsection{Leopold Cajetan Ledenig}

Einladung zur Pränumeration auf die vom Herrn Leopold Ledenig, für den Carneval des Jahrs 1830 verfaßten 6 Laibacher Deutsche mit Trio's im lithographirten Piano-Forte-Auszüge. (Neunter Jahrgang.) Die besondere Theilnahme, welche Herrn Ledenig's in diesem Zweige seit acht Jahren gelieferte Arbeiten bisher vielseitig gefunden haben, veranlaßt das Zeitungs-Comptoir auch heuer, die Verehrer der deutschen Tanzmusikzur gefälligsten Pränumeration auf diese neuen Producte des Herrn Verfassers mit der Versicherung geziemend einzuladen, daß dieselben weder in Beziehung auf den inneren Werth, noch auf die äußere Ausstattung den bisherigen, stets mit Beyfall aufgenommenen Lieferungen nachstehen werden. Der Pränumerationspreis ist für ein Exemplar 30 kr.C.M. der nachherige Ladenpreis aber 40 kr.C.M.

Source: LZ (IB), 19 Nov 1829, 644; 24 Nov 1829, 650.

Nachdem die lithographirten Piano-Forte-Auszüge der nächstjährigen Laibacher Redout-Deutschen des Herrn L. Ledenig, nächstens hier eintreffen werden: so wird der Termin der Pränumeration auf dieselben zu $30 \mathrm{kr}$. pr. Exemplar bis inclusive 10. Jänner 1830, mit dem Bemerken festgesetzt, daß der 
Ladenpreis zu $40 \mathrm{kr}$.pr. Exemplar eintrete. Ferner wird zur Kenntniß gebracht, daß in diesem Zeitungs-Comptoir auch noch Exemplare der beliebten Deutschen desselben Herrn Verfassers vom Jabre 1829, zu haben sind.

Source: LZ (Anh.), 29 Dec 1829, [1127]; LZ (IB), 2 Jan 1830, 4; LZ (AB), 5. Jan 1830, 14.

In der lithographischen Verlags-Handlung des Joseph Franz Kaiser ist neu erschienen, und das Exemplar um 24 kr.CM. zu haben: [...] 6 Redout-Deutsche mit Trios für den Carneval 1830, von Ledenig, gewidmet der Freyinn von Schmidburg.

Source: GZ (SIB), 7 Jan 1830, 32; 14 Jan 1830, 63; 19 Jan 1830, 88; 25 Jan 1830, 108; 26 Jan 1830, 120; 18 Feb 1830, 229.

Die lythographirten Piano-Forte-Auszüge der dießjährigen Laibach RedoutDeutschen des Herrn Ledenig, sind bereits eingelangt. Die (P. T.) verehrten Abnehmer, welche sich hierauf entweder in diesem Zeitungs-Comptoir, oder auf dem Roll-Bogen pränumerirt haben, werden sonach ersucht, die bestellten Exemplare in diesem Zeitungs-Comptoir gefälligst abholen zu lassen. In demselben sind derley Exemplare auch ausser der Pränumeration fortwährend zu 40 kr. pr. Stück, so wie auch Exemplare der vorjährigen Deutschen des genannten Herrn Verfasser zu haben. Desgleichen können auf Arrangement der dießjährigen Deutschen für Flöte und Guitarre à $40 \mathrm{kr}$. pr. Exemplar Bestellungen gemacht werden.

Source: LZ (IB), 19 Jan 1830, 36.

Copy: Laibacher Redout-Deutsche mit Trio's für das Jahr 1830 verfasst, für das Piano-Forte eingerichtet und dem hochgebornen Fräulein ELISE Freyin von Schmidburg hochachtungsvoll gewidmet von Leopold Cajetan Ledenig. (Neunter Jahrgang.) Lithogr. bei Jos. Fr. Kaiser in Gratz. NUK.

\section{$\mathbf{5 0 . 1 8 3 0}$ [Author not named]}

Bei J. C. Licht, Buchbändler in Laibach sind zu haben: Sechs neue Laibacher Schießstatt-Deutsche mit Trio's für den Carneval des Jahres 1830, im ClavierAuszuge, das Exemplar à $36 \mathrm{kr}$. Auch werden allda Bestellungen von diesen Deutschen für alle möglichen Arrangements gegen die billigsten Preise angenommen.

Source: LZ (AB), 22 Dec 1829, 1122; 24 Dec 1829, 1105; LZ (IB), 31 Dec 1829, 706.

\subsection{Joseph Bosizio}

Die vom Herrn Joseph Bosizio für den hiesigen Carneval componirten RedoutDeutschen im Clavier-Auszuge, werden mit Ende dieser Woche in einer eleganten Auflage in Wien bei Haslinger, im Kupfer gestochen, in dem hiesigen ZeitungsComptoir und bei Herrn Paternolli zu 30 kr. das Stück, vorräthig seyn.

Source: LZ (Anh.), 1 Jan 1831, [1]; 4 Jan 1831, [13]; LZ (IB), 8 Jan 1831, 18. 
Die in der vorigen Woche vorläufig angekündigten, von dem Herrn Joseph Bosizio für den heurigen Carneval componirten Redout-Deutschen sind bereits im Clavier-Auszuge erschienen, und bei Herrn Paternolli am Hauptplatze, so wie im biesigen Zeitungs-Comptoir zu haben. Der Preis für ein Exemplar beträgt nur bis Ende des Monats Jänner 1831, 30 kr., und wird seit 1. Februar 1831 auf $40 \mathrm{kr}$. erhöhet.

Source: LZ (Anh.), 18 Jan 1831, [49]; LZ (AB), 20 Jan 1831, 54; 22 Jan 1831, 65; LZ (Anh.), 10 Feb 1831, 49.

Copy: LAIBACHER REDOUTE-DEUTSCHE für den Carneval des Jahres 1831. Componirt, für das Piano-Forte eingerichtet und der Woblgebornen Frau MARIE WAGNER gebornen SCHMIDHAMMER hochachtungsvoll gewidmet von Joseph Bosizio. Stich und Druck aus Tob. Haslingers Officin in Wien. NUK.

\subsection{Julius Fluck von Leidenkron}

Pränumerations-Anzeige. In diesem Zeitungs-Comptoir wird auf die im lithographirten Piano-Forte-Auszuge erscheinenden Laibacher RedoutDeutschen für das Jahr 1831, von Julius Fluck, Pränumeration zu 30 kr. pr. Exemplar angenommen.

Source: LZ (Anh.), 30 Dec 1830, [1209]; LZ (AB), 1 Jan 1831, 4; LZ (IB), 4 Jan $1831,7$.

Copy: SIX VALSES AVEC TRIO Composèes et arrangèes Pour le Piano-Forte et dedièes á MADEMOISELLE ALBERTINE NOBLE DE BUZZI par Jules Fluck. Lith. Bey Jos. Fr. Kaiser in Graz 1831. NUK (incomplete).

\subsection{Leopold Cajetan Ledenig}

Pränumerations-Anzeige auf die für den Carneval des Jabres 1831 neu verfaßten Laibacher Redout-Deutschen sammt Trio's von Herrn Leopold Cajet. Ledenig. (Eilfter Jahrgang,) welche im geschmacksvoll lithographirten PianoForte-Auszüge erscheinen werden, wird in diesem Zeitungs-Comptoir zu 30 kr.C.M. pr. Exemplar Pränumeration angenommen. Da diese Pränumeration nur bis Ende dieses Monats December offen bleibt, so werden die P. T. verehrten Freunde der bekannt lieblichen Muse des Herrn Verfassers hiermit ergebenst eingeladen, ibre gefälligen Bestellungen noch zur gehörigen Zeit zu machen. Ignaz Edel v. Kleinmayr'sches Zeitungs-Comptoir.

Source: LZ (AB), 4 Dec 1830, 1160; 14 Dec 1830, 1164; LZ (IB), 16 Dec 1830, 648; 18 Dec 1830, 650; 23 Dec 1830, 660; 28 Dec 1830, 668; 1 Jan 1831, 5; LZ (Anh.), 30 Dec 1830, 1212; LZ (AB), 18 Jan 1831, [49].

Die P. T. Pränumeranten auf die dießjährigen Laibacher Redout-Deutschen des Hrn. Leopold Ledenig werden hiermit geziemend ersucht, ibre, entweder in diesem Zeitungs-Comptoir, oder auf dem Rollbogen pränumerirten Exemplare der lithographirten Piano-Forte-Auszüge in dem unterzeichneten Comptoir 
gefälligst abholen zu lassen. Zugleich wird zur Kenntniß gebracht, daß noch fortwährend derlei lithographirte Piano-Forte Auszüge der genannten Deutschen, jedoch zu dem Ladenpreise à 40 kr.C.M. pr. Exemplar in diesem Zeitungs-Comptoir zu haben seyn werden. Ignaz Edel v. Kleinmayr'sches Zeitungs-Comptoir.

Source: LZ (IB), 20 Jan 1831, 38; LZ (Anh.), 10 Feb 1831, 49.

\subsection{1 [Author not named]}

Zwischen dem 1sten und 2ten wie auch zwischen dem 3ten und 4ten Akte, wird eine Parthie neuer, für das Jahr 1831 von einem P. T. Dilettanten komponirter Redout-Deutschen, vorgetragen werden.

Source: NMS, Comedien-Zettel Sammlung, 1830/31,15 Jan 1831.

\subsection{Caspar Maschek}

Pränumerations-Anzeige auf 18 deutsche Tänze für den Carneval 1832 unter dem Titel: Fra Diavolo-Walzer, für das Forte-Piano in drei Theilen. Auswabl des Schönsten und Anmuthigsten aus Auber's beliebter Oper: Fra Diavolo, herausgegeben und gesetzt von C. Maschek. Unter obigem Titel erscheint eine geschmackvolle Auswabl der reizenden Motiven aus oben benannter Oper. - Nur der Kern des Schönsten, Anmuthigsten, und überhaupt des Gefälligsten wurde dazu benützt. Diesen Tänzen gehört der Vorzug, daß sie leicht, einfach, fäßlich und besonders auch zu Anwendung in Familien-Cirkeln für die Jugend wie für erwachsene geeignet sind. Ibre Reichbaltigkeit der Ideen, und der Umstand, daß sie für jede Gelegenheit zur Ausübung berechnet sind, mache sie überaus gemeinnützig. Pränumerations-Preis für alle drei Theile 1 fl. 30 kr.C.M. - Für einen einzelnen Theil 40 kr. Pränumeriert wird bei dem Herausgeber, Gradischka-Vorstadt, Nr. 4, im ersten Stocke, in Laibach. Nebst den Auszug für das Piano-Forte zu zwei und vier Händen, sind benannte Tänze auch für alle andern Instrumente zu haben.

Source: LZ (Anh.), 31 Jan 1832, [82]; LZ (IB), 4 Feb 1832, 67.

Die in den vorigen Zeitungs-Blättern angekündigten 18 deutsche Tänze für den Carneval 1832, unter dem Titel: Fra Diavolo-Walzer, in drei Abtheilungen, sind bereits bei dem Verfasser in Laibach, Gradischka-Vorstadt, Nr. 4, im ersten Stocke, zu haben.

Source: LZ (Anh.), 7 Feb 1832, [93]; LZ (AB), 11 Feb 1832, 99; LZ (IB), 14 Feb 1832, 84.

\subsection{Johann Strauss}

Bei Leopold Paternolli in Laibach sind [...] so eben angelangt, und zu haben: Die neuesten Productionen von Strauß, für den Fasching 1832, welche ibrer Vorzüglichkeiten wegen auch im Laibacher Redouten-Saale aufgefübrt werden, nämlich das Werk 47: Viva la Danse, für das Piano-Forte eingerichtet, à 30 kr.; 
dann das Werk 48: Heiter auch in ernster Zeit, für das Piano-Forte, à 30 kr.; und das Werk 49: Das Leben ein Tanz, der Tanz ein Leben, für das Piano-Forte allein, à 45 kr.; für eine Flöte 15 kr.; für eine Guitarre 30 kr.; für einen Czakan 15 kr.; für das ganze Orchester 2 fl.; für drei Violinen und Baß 1 fl.; für Violine und Piano-Forte $45 \mathrm{kr}$.

Source: LZ (IB), 14 Jan 1832, 26; 17 Jan 1832, 32.

Bei Paternolli in Laibach ist es eben angelangt: [...] empfielt er sich mit den Strauß'schen Laibacher Redout-Deutschen für 1832. Werk 47., 48. und 49., sowohl für das Piano-Forte als auch für mehrere andere Instrumente eingerichtet. Source: LZ (IB), 26 Jan 1832, 52; 28 Jan 1832, [53]; 31 Jan 1832, 60.

\subsection{Louis von Lazarini}

In den Zwischenakten wird die zweite Parthie von den heurigen RedoutDeutschen, von Baron Louis von Lazarini, aufgeführt.

Source: NMS, Comedien-Zettel Sammlung, 1833/34,12 Jan 1834.

\subsection{Johann Strauss}

In den zwischen-Akten wird die erste Parthie von den heurigen RedoutenDeutschen unter dem Titel „Der Frohsinn, mein Ziel“, von Johann Strauß, aufgeführt. Benannte Redout-Deutsche: „Der Frobsinn, mein Ziel“, sind im Clavier-Auszuge à $45 \mathrm{kr}$. an der Kasse, oder in der Wobnung der Unternebmerin [Amalia Maschek] in der Gradischa-Vorstadt Nro. 4, zu haben.

Source: NMS, Comedien-Zettel Sammlung, 1833/34, 8 Jan 1834.

\subsection{Adolph Müller}

Zwischen dem ersten und zweiten Akte werden neue Deutsche, vom Kapellmeister Müller, vorgetragen.

Source: NMS, Comedien-Zettel Sammlung, 1835/36, 17 Nov 1835.

\subsection{6 [Author not named]}

In den Zwischenakten werden neue Redout-Deutsche vom sämmtlichen Orchester-Personale aufgeführt werden.

Source: NMS, Comedien-Zettel Sammlung, 1835/36, 14 Jan 1836. 


\section{POVZETEK}

\section{Laibacher Deutscher po ljubljanskem kongresu}

Neposredno ob ljubljanskem kongresu (1821) je v Ljubljani zaživela oblika nemškega plesa z imenom Laibacher Deutscher in se približno eno desetletje obdržala v specifično lokalni obliki kot priljubljen ples meščanskih krogov. Slovensko poimenovanje tega plesa se ni nikoli ustalilo in ustrezna oznaka v slovenščini manjka še danes. Ljubljanski Deutscher je mogoče opisati kot epilog enega najstarejših evropskih družabnih plesov, hkrati pa tudi kot poskus restavracije starega družbenega reda in utrjevanja pripadnosti nemški kulturi.

Ne primarni viri ne sodobna literatura nemškega plesa ne pojmujejo enotno, zato nastaja vtis zgodovinske nepovezanosti te plesne oblike $\mathrm{z}$ alemando šestnajstega stoletja. Številne nejasnosti pri razumevanju povzroča dejstvo, da se je oznaka nemški ples (Deutscher Tanz) uporabljala kot nadpomenka. Bila je v rabi za vrsto plesov iz nemškega govornega prostora (npr. Deutscher, Dreier, Ländler, Schleifer, Steirisch, Straßburger, Schwäbischer Tanz in tudi valček). Pojavlja se tudi oznaka allemande, s čimer pa ni mišljena ne inštrumentalna glasbena oblika ne francoska plesna allemande 18. stoletja, temveč za evropski glasbeni trg privlačnejše poimenovanje Deutscherja.

V plesnih učbenikih Deutscher ni obširneje opisan, saj zaradi enostavnosti koraka in koreografskega poteka poglobljen pouk ni bil potreben. Omembe koreografskih struktur je med drugim mogoče najti v delu Erweiterung der Kunst Carla Josepha von Feldtensteina (1772), izvedbo tega skupinskega družabnega plesa pa je opisal tudi Johann Wolfgang von Goethe v romanu Trpljenje mladega Wertherja (1774). Bliže ljubljanskemu Deutscherju je plesna knjižica Georga Linka z naslovom Vollkommene Tanzschule, natisnjena leta 1796 v Celju. Link Deutscherja natančneje ne opisuje, a je v svoje skupinske družabne plese vpletel tudi koreografske elemente prav tega plesa.

Meščanska oblika Deutscherja se je izoblikovala na Dunaju v zadnjih desetletjih 18. stoletja. Tam se je hitrost plesa, predvsem pri figuri vrtenja, od lagodnega tempa vedno bolj stopnjevala in se okoli leta 1790 razvila v tako imenovani Langaus ter ob dunajskem kongresu (1814) v valček. Na Dunaju se je po letu 1770 izgubila figura prepletanja rok (Straßburger), kmalu pa tudi značilni obhod parov v krogu. Ob vzponu valčka pa Deutscher ni izginil. V njegovi senci se je v plesnih dvoranah obdržal vsaj še do zgodnjih tridesetih let 19. stoletja. Podobno kot v Ljubljani je bil priljubljen tudi v Gradcu, Celovcu in drugih mestih Avstrijskega cesarstva.

Deutscher je bil v Ljubljani znan že pred kongresom, a pred letom 1821 nastalih skladb skladatelji niso označevali kot Laibacher. Glasbo za te priljubljene in na plesnih prireditvah v Redutni in Streliški dvorani izvajane plese so prispevali poklicni in ljubiteljski skladatelji iz vrst ljubljanskega plemstva in uglednega meščanstva (Mašek, Mihevec, Ledenig, Lazarini in drugi) ter tudi tujci.

Ljubljanski Deutscherji so ohranjeni izključno v klavirskih izvlečkih, vrsta objavljenih nizov pa je znana le še po oglasih v tedanjem časopisju. Oblikovno so sestavljeni iz niza šestih Deutscherjev s trii. Njihova melodična, ritmična in oblikovna struktura je očitno odraz koreografskega poteka in je vse prej kot enotna, vsekakor pa se jasno razlikuje od takratnega valčka. Ples je prepoznaven po izpostavljenem zvoku trobil. Ljubljanski Deutscher se v širšem družbeno-kulturnem kontekstu in političnem ozadju izkaže za izjemno zanimiv fenomen. 


\section{ABOUT THE AUTHORS}

LIDIJA PODLESNIK TOMÁŠIKOVÁ (lidija.podlesnik-tomasikova@nuk.uni-1j.si) earned a Bachelor of Arts degree in music education from the Academy of Music (1992) and a Bachelor of Arts (1998) and Master (2013) in musicology from the Faculty of Arts (1998), all at the University of Ljubljana, Slovenia. Since 2015 she has worked as a librarian at the Music Collection of the National and University Library in Ljubljana, and before that (1997-2015) she was employed at the Department of Musicology Library at the Faculty of Arts of the University of Ljubljana. In 2010, she completed a specialized studies programme at the Institute for Historical Dance Practice (IHDP) in Gent under the supervision of Lieven Baert. She is the founder of the Cortesía Art Society and the artistic directior of the Cortesía Ensemble. In the Music and Movement elective course she has taught historical dance to students of the University of Ljubljana.

MARKO MOTNIK (marko.motnik@zrc-sazu.si) graduated from the University of $\mathrm{Mu}$ sic and Performing Arts, Vienna (MDW) with a Master's degree in organ performance and instrumental pedagogy, majoring in harpsichord. In 2010, following a programme of inter-university doctoral studies at the MDW and the University of Vienna, he received his doctorate with a dissertation on the work and reception history of Jacob Handl-Gallus. Motnik was employed as a postdoc university assistant within the Institute of Musicology at the University of Vienna (2010-2014) and at the MDW as a research fellow for the project Cultural Transfer of Music in Vienna (2010-2014). He then worked in the Archives of the Gesellschaft der Musikfreunde in Vienna (2016-2020). Since 2020, he has been a Research Associate at the Institute of Musicology, ZRC SAZU.

\section{O AVTORJIH}

LIDIJA PODLESNIK TOMÁŠIKOVÁ (lidija.podlesnik-tomasikova@nuk.uni-lj.si) je diplomirala iz glasbene pedagogike na Akademiji za glasbo v Ljubljani (1992) in muzikologije na Filozofski fakulteti v Ljubljani (1998), kjer je tudi magistrirala (2013). Od leta 2015 je redno zaposlena kot bibliotekarka v Glasbeni zbirki Narodne in univerzitetne knjižnice v Ljubljani, pred tem pa v knjižnici Oddelka za muzikologijo Filozofske fakultete Univerze v Ljubljani (1997-2015). V letu 2010 je zaključila specialistični študij v okviru Inštituta za historično plesno prakso (IHDP) v Gentu pod mentorstvom Lievna Baerta. Je ustanoviteljica KUD Cortesía in umetniška vodja Ansambla Cortesía. Na Univerzi v Ljubljani v okviru predmeta Glasba in gib poučuje stare plese.

MARKO MOTNIK (marko.motnik@zrc-sazu.si) je na Univerzi za glasbo in uprizarjajočo umetnost na Dunaju (MDW) zaključil umetniška magistrska študija koncertne smeri orgle in inštrumentalne pedagogike s predmetom čembalo. Leta 2010 je na MDW in Univerzi Dunaj doktoriral iz muzikologije s tezo o delu in recepciji del Jacobusa Handla-Gallusa. Na Inštitutu za muzikologijo Univerze na Dunaju je opravljal delo podoktorskega univerzitetnega asistenta (2010-2014), kot znanstveni sodelavec na MDW sodeloval pri raziskovalnem projektu Kulturni glasbeni transfer na Dunaju (2014-2016) in bil zatem zaposlen v arhivu dunajskega Glasbenega združenja (2016-2020). Od leta 2020 je kot znanstveni sodelavec zaposlen na Muzikološkem inštitutu ZRC SAZU. 